NBER WORKING PAPER SERIES

\title{
FINANCING INVENTION DURING THE SECOND INDUSTRIAL REVOLUTION: CLEVELAND, OHIO 1870-1920
}

Naomi R. Lamoreaux

Margaret Levenstein

Kenneth L. Sokoloff

Working Paper 10923

http://www.nber.org/papers/w10923

\author{
NATIONAL BUREAU OF ECONOMIC RESEARCH \\ 1050 Massachusetts Avenue \\ Cambridge, MA 02138 \\ November 2004
}

The views expressed herein are those of the author(s) and do not necessarily reflect the views of the National Bureau of Economic Research.

(C) 2004 by Naomi R. Lamoreaux, Margaret Levenstein, and Kenneth L. Sokoloff. All rights reserved. Short sections of text, not to exceed two paragraphs, may be quoted without explicit permission provided that full credit, including $(\mathrm{C}$ notice, is given to the source. 
Financing Invention During the Second Industrial Revolution: Cleveland, Ohio, 1870-1920

Naomi R. Lamoreaux, Margaret Levenstein, and Kenneth L. Sokoloff

NBER Working Paper No. 10923

November 2004

JEL No. N2, N6, O3

\begin{abstract}
For those who think of Cleveland as a decaying rustbelt city, it may seem difficult to believe that this northern Ohio port was once a hotbed of high-tech startups, much like Silicon Valley today. During the late nineteenth and early twentieth centuries, Cleveland played a leading role in the development of a number of second-industrial-revolution industries, including electric light and power, steel, petroleum, chemicals, and automobiles. In an era when production and inventive activity were both increasingly capital-intensive, technologically creative individuals and firms required greater and greater amounts of funds to succeed. This paper explores how the city's leading inventors and technologically innovative firms obtained financing, and finds that formal institutions, such as banks and securities markets, played only a very limited role. Instead, most funding came from local investors who took long-term stakes in start-ups formed to exploit promising technological discoveries, often assuming managerial positions in these enterprises as well. Business people who were interested in investing in cutting-edge ventures needed help in deciding which inventors and ideas were most likely to yield economic returns, and we show how enterprises such as the Brush Electric Company served multiple functions for the inventors who flocked to work there. Not only did they provide forums for the exchange of ideas, but by assessing each other's discoveries, the members of these technological communities conveyed information to local businessmen about which inventions were most worthy of support.
\end{abstract}

Naomi R. Lamoreaux Department of Economics University of California Los Angeles, CA 90095-1477 and NBER lamoreaux@econ.ucla.edu
Margaret Levenstein Institute for Social Research 426 Thompson Street University of Michigan Ann Arbor, MI 48106-1248 and NBER maggiel@umich.edu
Kenneth L. Sokoloff

Department of Economics University of California Los Angeles, CA 90095-1477 and NBER sokoloff@ucla.edu 


\section{Financing Invention during the Second Industrial Revolution: \\ Cleveland, 1870-1920}

Since the early nineteenth century, the United States economy has benefited from a legal, economic, and cultural environment that strongly encouraged technological innovation.

Nonetheless, there has been substantial change over time in the way new technological ideas

have been generated and exploited. In the early years, the dominant practice was for inventors to commercialize their ideas themselves. During the middle two quarters of the nineteenth century, however, there was a growing division of labor between those who invented and those who exploited inventions commercially. Most new developments during this period involved mechanical technologies, and consequently the amount of capital and formal education that an inventor needed to set up shop was relatively low. Firms were eager to secure patent rights to cutting-edge technologies, and many creative individuals learned to support themselves as independent inventors by selling their intellectual property in the market. By the end of the century, however, the more science-based technologies associated with the second industrial revolution had significantly raised the capital requirements (both human and physical) for effective invention, and inventors found it increasingly difficult to maintain their independence (Lamoreaux and Sokoloff 1999, 2002, 2003, and 2004).

This turn-of-the-century period is conventionally associated with the rise of R\&D laboratories inside large firms, but as we show in this article, it was also a time when large numbers of new enterprises were being formed in the "high-tech" sectors of the economy. Although some productive inventors gave up their independence and took employment positions in the research departments of large-scale enterprises, others became principals in start-ups or 
spin-offs formed to exploit their inventions. In some cases, these new firms effectively replicated the mid-nineteenth century division of labor. That is, they were essentially development facilities, organized to provide resources for the inventor's ongoing work and to market the resulting technologies to other enterprises. In most cases, however, the firms were organized with the aim of commercializing a particular line of technology with the inventor's assistance. Even in these cases, however, inventors often obtained space and resources to continue their inventive activity—facilities that often subsequently evolved into R\&D labs.

New firms, we argue, provided much of the technological leadership in second-industrialrevolution industries. This leadership was especially pronounced in the East North Central region of the country. Indeed, the formation of new firms seems to have thrived in an area that was located, much like Silicon Valley in the late twentieth century, at a significant distance from the nation's main capital markets and established financial institutions. It is thus of particular interest to understand the locational dynamics of this phenomenon-how inventors in such a region were able to attract the attention and resources of those with capital, why investors there were particularly willing to risk funds in such ventures, and what the role of formal financial institutions was in supporting the formation of new firms.

Because such questions can really only be answered in the context of a local case study, we focus our analysis on Cleveland, Ohio, a city that played a leading role in the development of a remarkable number of second-industrial-revolution industries, including electric light and power, steel, petroleum, chemicals, and automobiles. In the next two sections, we provide an overview of Cleveland's industrial and financial development and place our study in context by comparing data on Cleveland inventors to similar information for a nationwide sample of inventors. We then show how Cleveland's initial locational advantages were magnified, perhaps 
serendipitously, by a small number of successful enterprises that both exemplified the wealthcreation possibilities of these new technologies and served as hubs of overlapping networks of inventors and financiers. Focusing on one of the most important of these hubs- the Brush Electric Company-we show how such enterprises served multiple functions for the inventors who gathered around them. On the one hand, they were places that fostered technological crossfertilization and the exchange of ideas about how to solve particularly difficult problems. On the other hand, they were places where the technological community could pass on-validatepromising ideas and thus perform a useful vetting function for local capitalists. This validation not only opened up sources of venture capital to startup firms connected to the "hub" or nodal firm, but also plugged these enterprises into the network of formal financial institutions that local capitalists were simultaneously building, giving them access to commercial credit and ultimately to the possibility of raising additional capital on a formal local exchange.

\section{The Rise of Cleveland}

Located on Lake Erie at the terminus of the Ohio Canal, Cleveland had long been the commercial center of northeastern Ohio, but it became a manufacturing powerhouse during the last third of the nineteenth century. Cleveland's first heavy industrial enterprise, a firm that produced steam furnaces, was founded in the 1830s, and its first iron rolling mills were built in the $1850 \mathrm{~s}$, but the city's rise as a manufacturing center was largely a post-Civil War phenomenon (Miller and Wheeler 1990, 50-51, 70-71). As late as 1870, Cuyahoga County, where Cleveland is located, ranked number twenty-two in manufacturing output among counties nationwide; by 1920, it had risen to fourth place (over the same period Cleveland's ranking in terms of population rose from 20 to 7) (U.S. Bureau of the Census 1860-1920). Intriguingly, although the 
average size of firms in the county rose over the same period, the local economy continued to be characterized relatively small enterprises (see Table 1). In 1870, the county ranked number sixty-six among the hundred largest manufacturing counties in terms of the average number of workers employed per establishment. In 1920 its rank on this scale was still only fifty-two. Although some Cleveland enterprises grew very large, high rates of formation of new firms kept the average size of firms low. ${ }^{1}$

Many of the new firms founded in Cleveland during the late nineteenth and early twentieth centuries were in industries associated with the second industrial revolution. Cleveland's location gave it convenient access to Lake Superior iron ore, so it is not surprising that iron and steel was the city's leading industry (in terms of value of output) throughout the nineteenth century, falling to second place in 1910 and to third in 1920 (see Table 2). Machine tools was also persistently among the city's top three industries throughout the period 1870 to 1920. By 1910, however, automobiles had become the third largest industry, and it would climb to number one by 1920. During that same decade electrical machinery rose to fourth place, so that the city's top industries by 1920 were automobiles, machine tools, iron and steel, and electrical machinery. Chemical products, such as paints and varnishes, also had a major presence in the city and its surrounding areas. ${ }^{2}$

Cleveland's financial sector also grew rapidly over the half-century between 1870 and 1920. In 1870, the city was home to five national banks, most of which were originally founded in the 1840s, and one very substantial savings institution, the Society for Savings founded in

\footnotetext{
${ }^{1}$ From 1880 to 1900 the number of firms in Cuyahoga County tripled with little or no change in their average size. During the first decade of the twentieth century, however, the number of firms in the city fell by a third, despite continued growth in employment and output. As a consequence, average firm size nearly doubled. Between 1910 and 1920, however, the number of firms rebounded and the average size of firms did not change.

${ }^{2}$ Cleveland was also, of course, the home of Standard Oil, and petroleum refining was the city's third largest manufacturing industry in 1890. As the locus of crude-oil production shifted to other regions, however, the city's refining capacity declined.
} 
1849 , with total deposits under $\$ 0.5$ million. By 1920 , the city was home to thirty-eight banks, savings institutions, and trust companies with total deposits amounting to more than $\$ 800$ million. More than a dozen national banks were founded during this period, though because of mergers, the net gain in number over the entire period was only two. After the Ohio legislature passed enabling legislation, a dozen trust companies were organized, eleven of which remained active through this period. Similarly, an 1868 law permitting the formation of building-and-loan and savings-and-loan associations stimulated a rash of entry, but many of these institutions were short-lived. $^{3}$

From the 1816 founding of Cleveland's first bank, the Commercial Bank of Lake Erie, the city's leading businessmen were active in founding its most important financial institutions, so it is not surprising that industrialists played significant roles in organizing and running many of the banks and trust companies formed after $1870 .{ }^{4}$ For example, Robert Hanna helped to organize the Ohio National Bank in 1876, eight years after founding the Cleveland Malleable Iron Company. His nephew and partner, Marcus Hanna, organized the Union National Bank in 1884, served as its president for at least a decade, and also subsequently served on the board of the Commercial National Bank, the Guardian Trust Company, and the People's Savings and Loan Association. ${ }^{5}$ Similarly, C. A. Grasselli, a leading chemical manufacturer, was founder and president of the city's first trust company, Broadway Savings and Trust (1884), and also its second trust company, Woodland Avenue Savings and Trust (1886). ${ }^{6}$ Prominent among the founders of the Cleveland Trust Company (1895) were Fayette Brown, president of the Brown

\footnotetext{
3 "Banks and Savings and Loans," Encyclopedia of Cleveland History.

${ }_{5}^{4}$ Cleveland Plain Dealer, 14 July 1892, p. 13.

${ }^{5}$ Cleveland Plain Dealer, 14 July 1892, pp. 1, 6; "Eberhard Manufacturing Company," “M. A. Hanna Company," and "Marcus Alonzo Hanna," Encyclopedia of Cleveland History; Croly 1965.

6 "Our Prominent Men: Leading Spirits of the Younger Financial Institutions," Cleveland Plain Dealer, 22 March 1887, p. 1. See also 7 July 1892, p. 13.
} 
Hoisting Machine Company, and Jacob D. Cox, owner of the Cleveland Twist Drill Company. ${ }^{7}$ Brown's son, Harvey H. Brown, who replaced him as president of the Hoisting Company, served on the board of the Bank of Commerce. ${ }^{8}$ Many savings institutions also had industrialists among their organizers. For example, the founding board of directors of the Detroit Street Savings and Loan included Theodor Kundtz, an inventor and manufacturer of sewing-machine cabinets and auto bodies, and E. R. Edson, an inventor and manufacturer of machinery for extracting oil and other products from fish. ${ }^{9}$

Cleveland's equity markets also developed during this period. Daily quotations of government bond prices first appeared in the Cleveland Plain Dealer in 1880, and by 1886 the daily lists included prices for the stocks of local banks, street railroad companies, iron mines, and "miscellaneous" securities, including industrials. Moreover, advertisements in the Plain Dealer offered shares for sale in companies such as the Cleveland Stock Yard Company, the Brush Electric Company, and Brush Electric Light and Power. The continued growth both of local brokerage houses and of trading in local securities resulted in 1900 in the formal organization of the Cleveland Stock Exchange. Although local brokers led the formation of the exchange, its founding members also included prominent Cleveland industrialists such as Harvey Brown, Jeptha Wade, and Daniel R. Hanna. ${ }^{10}$ As was the case for most other exchanges at that time, railroads initially dominated the listings. But the Cleveland market from the beginning handled the securities of a broader diversity of firms, including relatively more industrials. For example, 52 percent of the firms listed on the New York Stock Exchange in 1900 were railroads, and in

\footnotetext{
${ }^{7}$ Minutes of the Board of Directors of the Cleveland Trust Company, 1903-1906, Container 12 (19031910), Folder 125, Ameritrust Corporation Records, Ms. No. 4750, Western Reserve Historical Society.

${ }^{8}$ Cleveland Stock Exchange Handbook, 1903.

${ }^{9}$ Cleveland Stock Exchange Handbook, 1903; Minutes of the Detroit Street Savings \& Loan, 1895-1901, Container 1, Folder 1, Ameritrust Corporation Records.

${ }^{10}$ Cleveland Plain Dealer, 5 Oct. 1900, p. 5.
} 
1910 the figure was still 48 percent. In 1903, railroads accounted for only 40 percent of the listings on the Cleveland exchange, and by 1910 the share had fallen to 15 percent. Over the same period, the share of industrials on the Cleveland exchange rose from 10 to 15 percent, and in 1910 the exchange also listed ten local telephone companies. ${ }^{11}$

\section{Cleveland Inventors in National Context}

By the late nineteenth century, Cleveland was not only a center of production in second industrial revolution industries, it was also a hotbed of patenting. In 1900 it ranked eighth out of all U.S. cities in the total number of patents granted to residents. Moreover, if the calculation is limited to patents deemed by official examiners to have made significant contributions to the industrial art of the period, Cleveland was the fifth most technologically important city in the country (Fogarty, Garofalo, and Hammack n.d., 43-46). The purpose of this section is to set Cleveland's patenting record in the context of changes that were occurring in the organization of inventive activity across the United States. We show that, at a time when many productive inventors appear to have been taking employment positions in large-scale enterprises, inventors residing in Midwestern cities such as Cleveland were disproportionately likely to become principals in firms formed to exploit their inventions.

As we have already suggested, the increase in patenting activity that occurred in the midnineteenth century U.S. was associated with a rise in the proportion of inventions attributable to highly productive inventors. Many talented individuals took advantage of the period's vibrant market for technology to specialize in the generation of inventions, financing their creative work

${ }^{11}$ Cleveland Stock Exchange Handbook, 1903 and 1910. Even after ten years in operation, most trading in local securities probably did not occur under the auspices of Exchange. Of the 105 firms it listed in 1910, the Exchange reported trades for only twenty-six firms, amounting to total sales of approximately 40,000 common shares and 20,000 preferred shares. 
by selling off the rights to their patents. By the early twentieth century, however, this "golden era of the independent inventor" was coming to an end, to a large extent, we argue, because the rising amount of capital (both human and physical) required for effective invention was making it increasingly difficult for inventors to survive on their own (Lamoreaux and Sokoloff 1999, 2002, 2003, and 2004; Hughes 1989, 15).

This change is visible in the assignment behavior of a nationwide sample of more than five hundred patentees whose surnames began with the letter "B." "12 The sample was generated, first, by drawing three random cross-sectional samples from the lists of patents reported in the Annual Reports of the Commissioner of Patents for the years 1870-71, 1890-91, and 1910-11, and then, for those patentees whose last names began with "B," collecting data on all patents received during the twenty-five years before and after they appeared in our samples, including whether and to whom the patents were assigned at issue. Table 3 divides the inventors into three different cohorts (according to the cross-sectional sample from which they were originally drawn) and also by the number of patents they obtained over their careers. It then categorizes each of their patents according to whether or not it was assigned at issue, and if it was, whether the assignment was in whole or part to an individual or to a company. Assignments to companies were classified in the following way. We first checked to see whether the assignee was a company with the same name as the patentee (indicating that the inventor was likely a principal in the firm). If not, we classified as "large integrated companies" all assignees for which financial information was reported in the Commercial and Financial Chronicle or in Poor's or Moody's Manual of Industrial Securities (indicating that the company was important enough to tap the national capital markets) or, alternatively, that were listed in an early-1920s

\footnotetext{
${ }^{12}$ For further discussion and analysis of these samples, see Lamoreaux and Sokoloff (1999a, 1999b, 2002, 2003, and 2004).
} 
National Research Council directory of companies with research laboratories. The remaining companies were divided into two groups: "other local companies," if the firm was located in the same city as the patentee; and "other companies" for all the rest.

Perhaps the most striking feature of the estimates presented in Table 3 is the widening contrast between the assignment behavior of the most specialized or productive patentees (those with 10 or more patents over their careers) and inventors who seem to have been much less specialized in this activity. By the 1910-11 cohort, the specialized inventors were assigning nearly two-thirds of their patents at issue, while inventors with 5 or fewer career patents were assigning only about a fifth. The identities of the assignees to which these two groups of inventors transferred their patents also diverged increasingly over time. Whereas inventors with five or less patents continued to assign mainly to individuals, often maintaining shares of the patents themselves, inventors with ten or more patents were overwhelmingly assigning their patents to companies. Moreover, by the third cohort, 22.5 percent and 37.7 percent of the patent assignments made by this group of productive inventors went respectively to large integrated companies and to firms that bore the name of the patentee. Indeed, virtually all of the patents assigned to large integrated companies came from inventors with ten or more career patents, and the share of this productive group in patents assigned to companies that bore the same name as the inventor was almost has high.

As Table 4 shows, these patterns had a pronounced regional character. Inventors, especially highly productive ones, in the Midwest (East North Central states) were disproportionately likely to assign their patents at issue to companies that bore their names: ${ }^{13}$ 56.7 percent of their assignments went to such firms and only 7.4 percent to large integrated

\footnotetext{
${ }^{13}$ Because the estimates in Table 4 were computed over all of the patents received by our sample of "B", inventors, it is the behavior of the more productive inventors that is most clearly reflected in our results. They received the most patents and thus get more weight in these averages.
} 
enterprises. The pattern in the Middle Atlantic was just the opposite, with 36.2 percent of assignments going to large firms and only 4.4 to companies with the inventor's name. New England was an intermediate case, with 35.4 percent of assignments going to large enterprises and an equivalent number to firms that shared the name of the inventor. Although regional differences in industrial composition might in principle account for these disparities, the same qualitative pattern holds when we control for the sectoral classification of the patents. ${ }^{14}$

That the increase in assignments to large firms did indeed represent a decline in the independence of inventors is suggested by the drop that occurred contemporaneously in what we call "contractual mobility"- that is, the number of different assignees to whom the inventor transferred his patents over the course of his career. As Table 5 indicates, after rising between the cohorts of 1870-71 and 1890-91, the proportion of patentees who assigned their patents at issue to four or more distinct assignees over their careers decreased between the 1890-91 and 1910-11 cohorts. The fall was greatest in the Middle Atlantic where the proportion of assignments going to large enterprises was highest. Intriguingly, contractual mobility actually increased in the Midwest, where inventors were most likely to assign their patents to firms that bore their name. It seems that patentees who were able to attract investment in enterprises formed to exploit their inventions were also able to maintain a significant degree of independence. $^{15}$

\footnotetext{
${ }^{14}$ As our theory would predict, inventors whose patents were classified as being in sectors that would normally be considered as having more technical or capital-intensive technologies, such as electricity/telecommunications or heavy industry, were much more likely to assign their patents at issue and to make assignments to large firms or firms that shared their name, than those whose patents were in sectors such as light manufacturing or agriculture/food processing. The different patterns across sectors do not account for the regional differences, however. For example, inventors who received patents classified as electricity/telecommunications or as heavy industry were much more likely to assign them to large companies (as opposed to firms with the same name) if they resided in the Middle Atlantic than if they resided in the East North Central states.

${ }^{15}$ As we shall see from the data on Cleveland, the relatively high proportion of patents not assigned in this region might also be taken as an indication of independence.
} 
As might be expected, inventors found it easier to obtain this kind of financial backing if they could demonstrate early in their careers that they had the "right stuff"the ability to generate economically valuable ideas. In Table 6 , we look at how the assignment behavior of inventors with ten or more patents evolved over their careers, using the earliest patent as the beginning of each inventor's career. ${ }^{16}$ For all three cohorts, there is evidence that patentees were better able to transfer their property rights later in their careers than at the beginning. The proportion of their patents that were not assigned at issue fell with the passage of years, as did the proportion of those assigned in which the patentee maintained an interest. There is also evidence that those who managed to find a market for their early inventions were better able to pursue successful careers at invention. Indeed, what is most striking about the evidence in the table is the disproportionate extent to which assignments to companies bearing the inventors' name occurred in the later phases of patentees' careers. For the last (1910-11) cohort, only 1.3 percent of the patents obtained by inventors in the first five years of their careers went to companies that bore the patentee's name. During the next ten years of their careers the figure increased to 17.1 percent and, after 15 years had elapsed, to 32.6 percent. There was a similar, though less pronounced, pattern in assignments to large integrated companies. While inventors often had to establish track records before they could secure good R\&D positions with large firms, it appears that it was especially important for them to prove their inventive skill, either as independent inventors or as employees, in order to obtain backing for start-up or spinoff ventures.

The purpose of our case study of Cleveland was to obtain, through detailed analysis of local sources, a more concrete sense of how such talented inventors were able to attract the attention and funds of the businessmen who would commercialize their technological

\footnotetext{
${ }^{16}$ Unfortunately, small cell sizes preclude a regional breakdown of this table.
} 
discoveries. The first step was to contextualize our study by exploring the extent to which patterns of inventive activity in Cleveland were similar to those in the Midwest as a whole. To this end, we collected samples of patent data for two groups of inventors resident in Cleveland at the beginning of the twentieth century. For each group, we sought to identify patentees who were likely to be among the most productive or specialized inventors of their cohort. The first group (36 in number, accounting for 22.4 percent of the patents awarded to Cleveland patentees in 1900) included inventors who met the following criteria: they received at least one patent in 1900, were also awarded a patent in either 1898 or 1902, and received a total of at least three patents in those three years. We then collected information on all of the patents awarded to these individuals in selected years from 1892 to 1912 . We also added to this group several additional Cleveland inventors who were sufficiently prominent to be profiled in the Dictionary of American Biography and who secured patents during these years. For our second group, we followed a somewhat different procedure. We compiled a list of all Cleveland inventors who were awarded patents in 1912, examined their patenting records in 1910 and 1911, and then selected the subset who received three or more patents in 1910, 1911, and 1912. This group included 107 inventors who collectively received 43.9 percent of the patents awarded to Cleveland inventors in 1912.

Our next step was to collect as much information about these productive inventors as we could. By consulting city directories for Cleveland, we were in most cases able to determine whether the inventors were principals or employees of the firms to which they assigned their patents or whether they had no such long-term attachments with their assignees. For many inventors, moreover, we were able to obtain additional information that provided insight into their patenting careers and the ways in which they obtained financing for their activities. This 
information came from mainly from manuscript collections, histories of individual firms, biographies and autobiographies, specialized encyclopedias, and contemporary newspaper reports. The results for the first sample are reported in the Appendix.

As Table 7 shows, both groups of Cleveland inventors displayed roughly the same pattern of assignments that we observed in our national sample for the East North Central states. The proportions of patents assigned at issue, and the proportions assigned to companies are similar to the figures for the 1890-91 and 1910-11 cohorts reported in Table 4. For example, the 1910-11 cohort of East North Central inventors assigned at issue 55.4 percent of their patents overall and 5.2 percent to individuals, as compared to 55.2 percent and 4.5 percent for the $1910-12$

Cleveland inventors. But there were also some discrepancies. For example, assignments to large integrated companies appear to have been relatively more common, and assignments to related companies (as indicated by the company's name or by the position of the inventor) somewhat less so, among Cleveland inventors than those in the East North Central as a whole, but the difference may be attributable to Cleveland's status as one of the largest industrial cities in the region. This notion receives some support from the figures reported in Table 8, which breaks down the inventors in the first sample by the number of patents each obtained during this period. We see that assignments to large integrated companies were disproportionately the work of productive inventors who were employees of firms (or at least were not principals). For example, Clinton A. Tower, a foreman and pattern maker for the National Malleable Castings Company, assigned the bulk of the 17 patents he obtained in our sampled years to his employer (see Appendix). Because Cleveland was home to a significant number of large companies, it was also home to the inventors who worked for them. 
More importantly, however, the evidence shows that many productive inventors in Cleveland, like their counterparts in the East North Central states as a whole, assigned their patents to firms in which they had a direct interest. Indeed, from the information we were able to collect from local sources, we can see that they typically served as officers of such enterprises. Despite their close attachments to such firms, however, productive patentees in Cleveland seem to have been able to maintain a considerable degree of independence. In this way too, they resembled their counterparts throughout the region. Although our data do not allow us to calculate measures of contractual mobility, in Table 8 we can see that the assignment patterns of highly productive inventors who were principals in firms were very different from those of highly productive inventors who were not. Although the former group made nearly 75 percent of their assignments to the companies in which they were principals, they had strikingly lower rates of assignment at issue (39.0 percent on average) than the other highly productive patentees in the sample (74.7 percent). That they were able to retain ownership of such a high fraction of their patents suggests that they maintained a remarkable degree of autonomy vis à vis the other owners of their firms. ${ }^{17}$ Because these other owners included the main suppliers of capital to their enterprises, the question naturally arises how inventors were able to secure financial backing under such circumstances.

\section{The Brush Electric Company}

At the simplest level, before they would be willing to invest in new technological ventures, wealthy individuals had to be convinced of two things: first and most obviously, that it

\footnotetext{
${ }^{17}$ It is worth noting that our examination of the more comprehensive listings of patent assignments currently stored at the National Archives for several of these highly productive inventors (including Sidney Short and Elmer Sperry) suggests that a number of their patents were assigned after issue.
} 
was indeed possible to earn high rates of return by putting their money in this kind of enterprise; and second, that the particular technologies in which they were being asked to invest promised significant returns. All that was really needed to satisfy the first condition was some enticing examples of ventures that had made their backers rich. The second was more difficult, however, because evaluating the merits of alternative projects required considerable technological expertise. Our research on the financing of new enterprises in Cleveland suggests that a few highly successful enterprises could help satisfy the second condition as well as the first. As the following analysis of the Brush Electric Company illustrates, such firms could provide powerful demonstrations of the high profits that investing in cutting-edge technology could generate. At the same time, by serving as the hub of overlapping networks of inventors and investors, they could both stimulate ongoing inventive activity and provide the expertise needed to assess the economic merits of the resulting discoveries.

Charles F. Brush, the inventor at the heart of the Brush Electric hub, had been interested in electricity from an early age and had built his first arc light while still a student at Cleveland High School. During the late 1860s, Brush attended college at the University of Michigan, majoring in mining engineering because the school did not yet have a program in electricity. He then returned to Cleveland and attempted to earn a living as an analytical chemist, joining an iron-dealing partnership with Charles Bingham, a childhood friend, when he found he could not make ends meet. All the while, he continued to experiment in his spare time with electric lighting (Kennedy 1885; Brush 1905; Gorman 1961; Eisenman 1967, 11-26).

Another long-time friend, George Stockly, provided Brush with the opportunity to pursue his electrical interests more seriously. Stockly was vice president and general manager of the Telegraph Supply Company, and he hired Brush to do some consulting work for the firm. The 
two men got talking about the future of electricity, and Stockly, impressed by Brush's ideas, offered him the use of the company's shop to develop his arc-lighting system. ${ }^{18}$ When Brush successfully demonstrated a new dynamo, Stockly negotiated a contract that gave Telegraph Supply exclusive rights to market the device in exchange for royalties. Brush's reputation as an inventor got a boost in 1878, when his dynamo won a competition at the Franklin Institute in Philadelphia, but it was the backing of Stockly and other officers of the Telegraph Supply Company that translated Brush's technical triumph into a commercial success. These officers included Mortimer D. Leggett, a patent solicitor who had served as the U.S. Commissioner of Patents, and banker James J. Tracy, who belonged to the "Ark," a club whose members were interested in natural science, and who was helping to found the Case School of Applied Science at around the same time. These men had both the technological expertise and the connections needed to raise the capital for the new venture. ${ }^{19}$

Looking for a dramatic way to publicize Brush's invention, Stockly and his associates negotiated a contract with the city of Cleveland to light Monumental Park (now Public Square). Advance publicity brought out a large crowd the evening of April 29, 1879, when Cleveland officials threw a switch, and twelve strategically placed arc lamps flooded the park with light.

\footnotetext{
${ }^{18}$ Intriguingly, other boyhood friendships did not have similar benefits. For example, Brush lived during his high school years at the same boarding house as John D. Rockefeller, who despite his great wealth was not a supporter of technological innovation. (In 1898 Elmer Sperry took Rockefeller for a ride in the electric automobile he had recently invented. Rockefeller refused to take over the controls and advised Sperry afterwards to move on to other things.) Later, however, Brush would join Frank Rockefeller in a real estate venture (Eisenman 1967, 18, 1623; Hughes 1971, 87).

${ }^{19}$ Typescript of address by Charles F. Brush to the Franklin Institute, 18 April 1929, Box 9, Folder 11; Letter from W. S. Culver to W. D. Stockley, 24 April 1928, Box 4, Folder 5, Charles F. Brush Collection, Kelvin Smith Library, Case Western Reserve University. See also Kennedy 1885; Stockly 1901; Brush 1905; Orth 1910, Vol. 2, 44-45; Gorman 1961; Eisenman 1967, 26-120; Rose 1950, 162; Cooper and Schmitz 1993, 10, 39-41; and "Brush, Charles Francis," "The Brush Electric Co.," "Electrical and Electronics Industries," "Leggett, Mortimer Dormer," and "Tracy, James Jared, Sr.," Encyclopedia of Cleveland History. See also the following documents: "Agreement between Charles F. Brush and Telegraph Supply Company," 7 June 1876, "Agreement between Charles F. Brush and Telegraph Supply Company," 24 Mar 1877, and"Memorandum of Agreement between Telegraph Supply Company and Charles F. Brush," 24 Mar 1877, all in Box 21, Folder 12, Charles F. Brush Collection, Kelvin Smith Library, Case Western Reserve University.
} 
News of the event spread quickly throughout the country, generating a rush of interest in this new type of street lighting, followed by orders for installations. The successful demonstration also helped the officers of Telegraph Supply line up investors, and the next year the firm was reorganized as the Brush Electric Company with an authorized capital of \$3 million, an enormous amount for the time (Brush 1905, Gorman 1961, Cox 1951, 90-91). ${ }^{20}$

Brush Electric installed about eighty percent of the nation's arc-lighting systems during the early 1880s and made the business people who initially bought its stock rich. As Jacob D. Cox, founder of the Cleveland Twist Drill Company, later regretfully noted: "The original holders made immense sums of money but, as I had no funds to invest, I missed this rare opportunity" (Cox 1951, 90-91). Brush himself became a wealthy man, earning royalties on his patents in excess of $\$ 200,000$ a year during 1882 and 1883 . Indeed, his royalty account accumulated so quickly that the company fell behind on its payments, and to settle the debt, Brush agreed in 1886 to take $\$ 500,000$ in stock. ${ }^{21}$ By the second half of the decade, however, the company was losing ground to new competitors, and Brush, Stockly, and the other major shareholders sold out to the Thomson Houston Electric Company at what appears to have been a handsome price (Eisenman 1967, 112-14, 118-20, 162-3; Rose 1950, 477). According to a report in the New York Times on January 21, 1890, the controlling shareholders (Stockly, Tracy,

${ }^{20}$ Subsequent negotiations between Brush and the company suggest that only half of the authorized capital was ever paid in. Brush himself did not take stock in the company until a number of years later. Instead, he agreed to assign all of his existing and future lighting-system patents to the enterprise in exchange for royalties. See "Memorandum of Supplementary Agreement between Brush and the Brush Electric Co. (formerly Telegraph Supply)," 1 Sept. 1880, and "Agreement between Brush and the Brush Electric Company," 27 July 1886, Box 21, Folder 12, Charles F. Brush Collection.

${ }_{21}$ As part of the deal, Brush Electric's capital stock was reduced from $\$ 3$ million to $\$ 1.5$ million fully paidin shares. The company then issued an additional $\$ 0.5$ million in stock for Brush. In addition, the company promised that, before making any dividends, it would pay Brush "an amount not less than one fourth part of the whole sum proposed to be divided, ... such payments to continue until [the company's] indebtedness shall be fully paid." "Agreement between Brush and the Brush Electric Company," 27 July 1886, Box 21, Folder 12, Charles F. Brush Collection. The royalty statements are in Box 15. Brush also sold his British and other foreign patents to the Brush Electric Light Corporation, Limited in England for a "very large price." According to a report published in Scientific American (2 April 1881, p. 211), "The sums paid for these foreign patents are ... greater than have ever been paid for any other foreign patents obtained by an American." 
Leggett, Brush, and Stockly's sister) owned 30,000 of the company's 40,000 outstanding shares and sold them for $\$ 75$ each. The par value of the stock was $\$ 50$, and its market price was estimated at that time to be $\$ 35$.

Whether the profits that these stockholders earned from their shares in Brush Electric had a demonstration effect that encouraged other local capitalists to invest in cutting-edge technologies is impossible to measure. ${ }^{22}$ There is no doubt, however, that the men most visibly associated with the Brush enterprise had a comparatively easy time raising capital for their subsequent ventures. A good example is Washington Lawrence, a major investor in the Brush Company and, for a time, its general manager. In 1882, Lawrence cashed out and invested the proceeds in real estate, but he returned to the industry in 1886 to buy a controlling interest in the Boulton Carbon Company, a spin-off venture that supplied carbons for arc lights to Brush Electric and other firms. Lawrence reorganized Boulton as the National Carbon Company, bringing in wealthy investors such as Myron T. Herrick, a local lawyer who had founded a hardware company and who built the Society for Savings into a major financial institution, and Webb C. Hayes, son of the ex-president. He then used this firm as a vehicle to acquire competing enterprises and expand into batteries and other components of electrical systems, in the process creating one of the country's earliest industrial research laboratories. ${ }^{23}$

22 There is evidence, however, that interest in investing in electrical startups was sufficiently elevated that con artists were able to organize "wild cat" companies, "whose only purpose seemed to be to foist a lot of worthless stock upon a gullible public." Henry I. Hoyt, president of the Gramme Electrical Company, a trust that temporarily included all the major electrical lighting companies in the country, claimed that one important purpose of the monopoly was to stamp out such practices. These wild cat companies, he claimed, owned no patents and displayed other companies' machines to gullible investors as if they were their own. "'Why, Sir,' exclaimed Mr. Hoyt, indignantly, 'I have even had men come to me and ask to borrow dynamo-electric generators to exhibit in the offices of the so-called "electric light companies." According to Hoyt, between forty and fifty such "speculative enterprises" were out raising capital (New York Times, 27 April 1881, p. 12).

23 "Lawrence, Washington H." and "National Carbon," Encyclopedia of Cleveland History; Orth 1910, Vol. $3,14-18,315-22$. 
Another good example of the ease with which men associated with Brush Electric could raise capital for innovative projects is Brush's own promotion of the Linde Air Products Company. Brush became aware during the 1890s of the work of Carl von Linde, a German scientist who had developed a process for liquefying air. Linde wanted to market his invention in the U.S. but was prevented by a conflicting patent. Believing that Linde's invention had priority, Brush bought a one-third share in the patent and financed the necessary litigation. The case dragged on for several years, but Brush ultimately won and, after a brief period during which he and Linde disagreed about terms, set about organizing the Linde Air Products Company. In early 1907, he held a meeting in his office to present a prospectus for the company to a small group of prominent Cleveland businessmen. Virtually all of those present immediately agreed to invest, and the company was launched with a capital of $\$ 250,000$ and with Brush as president, chemical entrepreneur C. A. Grasselli as vice president, and J. L. Severance of Standard Oil as Secretary-Treasurer. ${ }^{24}$ After some initial technical problems, which Brush himself resolved, the enterprise grew rapidly. By 1910, R. G. Dun \& Company gave it a credit rating of "excellent," despite having no information to measure its pecuniary strength, and by 1917 its authorized capital had increased to $\$ 15$ million. In the latter year, the firm merged with National Carbon, Union Carbide, and other firms to form Union Carbide and Carbon Company, with Brush and the other investors exchanging their Linde stock for twice the number of shares in the new combine. ${ }^{25}$

\footnotetext{
${ }^{24}$ See the following letters from Charles F. Brush: to Fred W. Wolf, 15 Feb. 1907, Cecil Lightfoot, 25 Feb. 1907, Carl Linde, 25 Feb. 1907, and Carl Linde, 5 Aug. 1907, Box 3, Folder 1, Charles F. Brush Collection.

${ }^{25}$ See Wall Street Journal, 15 Feb. 1917, p. 6, and 3 Oct. 1917, p. 2; R. G. Dun \& Company 1910 ; Eisenman 1967, 118-33, 162-3.
} 


\section{Brush as the Hub of a Network of Inventors}

The phenomenal profits that Brush and his associates earned in arc lighting gave them the clout they needed to command the attention and the funds of the city's capitalists, but such effects do not begin to capture the impact of Brush Electric on the technological development of Cleveland. Indeed, the company was from early on a magnet for ambitious young men who came to work in its shops, network with other technologically creative people, and catch the eye of investors eager to finance the next Charles Brush. Some of these young men were employees. For example, W. H. Bolton, founder of the Boulton Carbon Company (later National Carbon), was a foreman at Brush before organizing his spin-off enterprise in 1881 with capital supplied by Willis Masters, son of Irvine U. Masters, owner of a prominent Cleveland shipbuilding firm. ${ }^{26}$ Others, however, were independent inventors whose experiments Brush encouraged at least in part to increase the demand for his electrical equipment. Thus Walter H. Knight, an engineer, and Edward M. Bentley, a patent attorney, used the company's facilities in the early 1880 s to develop and patent an underground power cable (connected to a Brush generator) to operate an electric streetcar. ${ }^{27}$ Their position at Brush gave them sufficient visibility that they were able in 1884 to attract New York venture capital, organize their own firm, the Bentley-Knight Railway Company, and convince the East Cleveland Railway Company to lay a trial line. Although the initial experiment was successful and generated orders from companies in other cities, it soon became apparent that the technology did not work well in inclement weather. The company ran

26 "Masters, Irvine U." and "National Carbon," Encyclopedia of Cleveland History; Rose 1950, 476.

${ }^{27}$ We have not been able to find precise information about the terms on which Knight and Bentley and other companies used the Brush facilities. While Brush may early on have provided space and access to his machine shop to inventors in much the same way as Telegraph Supply had encouraged him, it is likely that, as time went on, inventors who ran their businesses out of the Brush complex paid rent. 
into financial difficulties, and Thomson-Houston bought out its shareholders in order to gain control of the Bentley-Knight patents. ${ }^{28}$

Similarly, another streetcar pioneer, Sidney H. Short, moved to Cleveland so that he could work in the Brush shops. Growing up in Columbus, Ohio, Short (like Brush) had early developed an interest in electricity, and he had amused himself as a child by equipping his parents' home with burglar alarms and other electrical devices. Later, while attending Ohio State during the late 1870s, he patented and sold a transmitter for telephones. Graduating in 1880, he accepted a professorial position at the University of Denver, where he taught physics and chemistry and pursued his research in electrical applications. Within several years he had demonstrated his "Joseph Henry," a trolley car driven by an electric motor around an elliptical track. In his own words, "so impressed were the capitalists then interested in my experiments that the Denver Tramway Company was at once organized" to build an electric streetcar in that city. Obtaining a contract for a system in St. Louis, he secured financial backing from an Ohio investor who arranged to have the necessary dynamos custom-made at the Brush Electric Company. Short then moved to Cleveland to supervise the work and experiment in the company's shops. Brush not only encouraged Short's efforts but helped to finance the resulting Short Electric Railway Company, which operated out of a Brush building. By that time, it seems that Short's reputation as an inventor was sufficiently well established that he was able to attract considerable outside investment. ${ }^{29}$

\footnotetext{
${ }^{28}$ This is another example of an ultimately unsuccessful venture that made a lot of money for its investors. The firm, which was organized in New York, was initially capitalized at \$1 million, with much of this amount being issued in exchange for patents. According to a report in the New York Times, "Interested parties, it is said, advanced the money for the development of the business" (1 Sept, 1889). See also New York Times, 9 Sept. 1884, p. 8; 6 Sept. 1888, p. 8, 29 Oct. 1889, p. 1, and 30 Oct. 1889, p. 9; Toman and Hays 1996, 32-33; and "Technology and Industrial Research," Encyclopedia of Cleveland History; Rose 1950, 402, 465.

${ }^{29}$ Short 1899; Smith 1955; Dictionary of American Biography; Moley 1962, 33-34.
} 
The career of John C. Lincoln, founder of the Lincoln Electric Company, provides further insight into the connections and opportunities that Brush's shop had to offer young would-be inventors. The son of an impoverished minister, Lincoln developed an interest in electricity during his high-school years and pursued it at Ohio State by taking all of the relevant courses the university offered. He also worked during his spare time for the company that installed Columbus's first electric streetcar line. With the help of a relative, he secured a position at Brush Electric in 1888, enrolling in the training course that Brush had created for his employees. About a year later, Brush introduced Lincoln to Short, who promptly hired him to assist in demonstrating and installing his electric streetcar system. While traveling in Short's employ, Lincoln obtained his first patent, an electric brake for streetcars, which he sold for $\$ 500$ to the great inventor Elmer Sperry (who was then also working on streetcars at the Brush facility). In 1892, Lincoln returned to Cleveland (and to Brush) as Short's superintendent of construction. When shortly thereafter General Electric bought the company, Lincoln joined forces with Samuel K. Elliott and his brothers, W. H. and Emmett, in an enterprise to sell electric motors. ${ }^{30}$ This venture too originated in a Brush connection, for Samuel was a fellow student in the training course. Lincoln designed a motor that quickly gained a respected place in the market, and in 1895 the four men organized the Elliott-Lincoln Electric Company with financial backing from members of a local family named Crawford. Times were hard, and Lincoln fought with his associates over the future direction of the business. Forced out of the company, in 1896 he started his own venture to produce electric motors, the Lincoln Electric Company. The firm's

\footnotetext{
${ }^{30}$ Virginia Dawson claims that Short fired Lincoln "for the failure of a motor manufactured by the Brush Electric Company," but she does not mention the sale of the firm to General Electric and does not provide a source for her account (Dawson 1999, 16). If this story is true, however, it might explain why Lincoln relied on his own savings to found Lincoln Electric.
} 
initial capital came from his own meager savings, ${ }^{31}$ but Lincoln was able to build up the business rapidly by custom designing motors for local firms. By the end of the next decade, Lincoln had spun off the production of motors to the Lincoln Motor Works (later Reliance Electric) with capital supplied by Cleveland industrialist Peter M. Hitchcock (a relative who was an early supporter of Brush and who had originally gotten Lincoln the job there), and was increasingly devoting his energies to the development of the arc-welding equipment for which the firm would become famous. In the meantime, he wrote a popular handbook on electricity that sold 40,000 copies, invented an automobile powered by a variable-speed electric motor that he considered his greatest invention, and designed generators for electric vehicles that allowed owners to recharge their car's batteries in their own garages. ${ }^{32}$

The Brush firm was also the incubator for the Cowles Electric Smelting and Aluminum Company, the brainchild of Eugene and Alfred H. Cowles, whose father was a prominent Cleveland newspaper publisher. Eugene began to study electricity and its possible uses for smelting after covering an early exhibit of Brush lighting for his father's paper. In 1880 he left the news business to organize and manage the Brush Electric Light and Power Company, the Brush affiliated utility in Cleveland. His brother Alfred was at that time studying physics and chemistry at Cornell, but the two brothers soon joined forces in New Mexico, where Eugene, a tuberculosis sufferer, had gone for health reasons and to inspect mining properties. The proximity of the mines to good sources of water power stimulated the brothers to pursue Eugene's ideas about electric smelting. Lacking the equipment they needed to experiment, they returned to Cleveland and to the Brush works, successfully built their first furnace, applied for a

\footnotetext{
${ }^{31}$ Indeed, it is claimed that Lincoln started the firm with $\$ 200$ or $\$ 250$ (the accounts vary) that he earned from designing a motor for Herbert Dow. When he incorporated the firm in 1906, however, it was capitalized at $\$ 10,000$ (Moley 1962, 42, 64; Dawson 1999, 17, 20).

${ }^{32}$ Moley 1962, 31-72; Dawson 1999, 11-31; "Lincoln Electric Co." and "Reliance Electric Co.," Encyclopedia of Cleveland History.
} 
patent, and in 1885 organized their company. ${ }^{33}$ Located initially at the Brush works, the firm operated four furnaces, each powered by a Brush dynamo. With capital supplied by their father, they built a larger plant in Lockport, New York, where they could obtain cheap power from Niagara Falls (the local Brush Electric Light and Power Company had generated the first hydro electricity there just a few years earlier). ${ }^{34}$ The company did well until 1893 when it was shut down by court order in a patent dispute. Although Cowles emerged from the litigation victorious with a hefty financial settlement in 1903 , ten years of enforced idleness had done its aluminum business irreparable harm, and it licensed its patents to the defeated party, the Pittsburgh Reduction Company, later ALCOA. Meanwhile, a group of investors had organized the Electro Gas Company to use the Cowles technology for the production of calcium carbide, the main component of acetylene gas. The application was discovered and patented by Thomas L. Willson, who had worked for a short-time at Brush and presumably had there become familiar with the Cowles's smelting methods. The Cowles Company received 12.5 percent of the capital stock of the new firm in exchange for a license to use its furnace patents. In 1898 Electro Gas was reorganized as Union Carbide, which, as we have seen, later merged with two other Brushrelated concerns, National Carbon and the Linde Air Products Company, to form the Union Carbide and Carbon Corporation. ${ }^{35}$

Inventors continued to gravitate to the Brush Electric shop even after Brush and his associates sold out to Thomson-Houston. It was there, for example, that Walter C. Baker

${ }^{33}$ It is interesting to note that Brush himself was initially skeptical that the process would prove practicable (Cowles 1958, 34). By 1886, however, Brush was using Cowles aluminum to make hubs for armatures (Scientific American, 15 May 1886, p. 303).

${ }^{34}$ The Cowles brothers may also have gotten financial help from Eugene's father-in-law, the wealthy private banker E. B. Hale, before the marriage ended in a spectacularly messy divorce that made national news in 1890. See New York Times, 10 June 1890, p. 1, 31 Aug. 1890, p. 1, 24 Dec. 1890, p. 6.

35 The contracts licensing to Electro Gas patents owned by Alfred H. Cowles and the Electric Smelting and Aluminum Company are in the British Alcan collection, UGD 347/21/27/15, Glasgow University Archives. For the history of the Cowles brothers and their firm, see Biography of Cowles 1927; Cowles 1958. 
invented his electric automobile, organizing the Baker Motor Vehicle Company in 1898 with the assistance of his father-in-law, Rollin C. White, one of the founders of the White Sewing Machine and Cleveland Machine Screw Companies. ${ }^{36}$ Around the same time, Elmer Sperry developed his own electric vehicle in the same facility. Sperry had originally been enticed to Cleveland (and to Brush) by Washington Lawrence and other major investors associated with National Carbon. Collectively known as the Sperry Syndicate, this group contracted with Sperry in 1890 to develop a prototype for an electric streetcar, promising that, if the prototype proved workable, the syndicate would either form their own company to build the cars or sell or license the patents to another company that would. This arrangement was really early stage financing. Although Sperry already had some patents in the area, he had not yet developed a working model. Sperry developed his streetcar over the next couple of years and, in 1892, the syndicate arranged to exploit the invention in a joint venture with the Thomson-Houston Electric Company (which a few months later became General Electric). The resulting Sperry Electric Railway Company contracted to pay Sperry a lucrative salary as consultant in addition to a share in the company's profits. ${ }^{37}$

When Sperry got interested in the idea of an electric automobile a few years later, he again turned to the syndicate for financial help. Their backing provided the support he needed to develop his vehicle (at Brush), which was then licensed to the Cleveland Machine Screw Company (Sperry received stock in the company and the position of electrical engineer). In 1900, the American Bicycle Company bought this business, along with Sperry's patents, and the next year assigned Sperry’s electric storage battery inventions to the National Battery Company.

\footnotetext{
36 “The Baker Motor Vehicle Company,” Men of Ohio 1914; Wager 1986, 205-18; "The Baker Materials Handling Co.," "Baker, Walter C.," and "Technology and Industrial Research," Encyclopedia of Cleveland History. ${ }^{37}$ Hughes 1971, 70-73; Cooper and Schmitz 1993, 11, 57; Rose 1950, 465 "Electrical and Electronics Industries," Encyclopedia of Cleveland History.
} 
Sperry helped to get this enterprise up and running and served for a short time as its general manager (Hughes 1971, 80-88; Hritsko 1988, 12-13; Wager 1986, 221-23).

The spate of mergers and buyouts that followed the formation of General Electric in 1892 also spurred a number of Brush-connected inventors to form independent enterprises. For example, employees of what had been Brush's lamp affiliate, the Swan Lamp Manufacturing Company, formed the Adams-Bagnall Electric Company in 1895 (Covington 1999). Similarly, as we have already seen, after Short sold his streetcar company to General Electric in 1893, Lincoln formed his first independent enterprise. Short himself reentered the business almost immediately by joining forces with the Walker Manufacturing Company, a cable and machinery builder, to develop an electric traction system. By this time, his abilities as an inventor in this promising new field of technology were so well appreciated that he was able to mobilize financial support on what seem to be remarkably favorable terms. For example, in a contract dated July 1, 1896, he agreed in return for generous compensation and the title of vice president to work for the company and to assign it the rights to all of his patents that he then owned and controlled, as well as to inventions he would patent in the future, in the areas of "Dynamo electric machinery, Street Railway motors and car equipment, Arclighting machinery, and Alternating machinery." Although we do not know what salary he received, his contract specified that he would be paid an additional royalty of " 20 cents per horse power upon all of the electrical apparatus sold and delivered to customers," and that the assignments of his patents would be revoked if the royalties due were not paid within three months of the delivery of the apparatus, or if the company failed to sell and deliver electrical equipment totaling at least $\$ 300,000$ in any calendar year. Most telling, however, is the contract's "reversionary clause," which specified that, if Short were to leave the employment of the Walker Company, the rights 
to all of his patents would revert back to him. The implication is that Short's participation in the company was so desirable that he was able to find individuals willing to invest in developing his technology, despite the fact that he had the right to withdraw at any time with all of the assets he had brought to the firm. ${ }^{38}$ Indeed, the next year a group of New York capitalists who were "largely interested in street railway and electric lighting systems in many of the principal cities" (they included ex-Governor Roswell P. Flower, Anthony N. Bradey, James W. Hinkley, and Perry Belmont, brother of August Belmont) bought a controlling interest in Walker and negotiated with Short and the company's other officers for the sale of the firm and its assets to Westinghouse in $1898 .^{39}$ Short then left for England to help set up a company that would exploit his traction patents in Europe. When he died suddenly of appendicitis in London in 1902, he left an estate valued at about two and a half million dollars (Smith 1955).

\section{The Limited Role of Formal Financial Institutions}

One of the most striking features of the foregoing company histories is the limited role played by formal financial institutions, not only in the formation of the original Brush Electric Company, but also in the many startups and spinoffs that came out of this hub. The entrepreneurs who organized and promoted these new ventures secured investment capital largely by relying on personal connections. These could be familial, as when the father of Eugene and Alfred Cowles provided most of the initial capital for the Cowles Electric Smelting and Aluminum Company; they could result from friendships, as when George Stockly agreed to support Brush's initial work in electrical lighting; or they could be based on the recommendations of men who

\footnotetext{
${ }^{38}$ Unfortunately, we have been unable to locate the employment contract between Short and the Walker Company. The assignment contract is dated July 1, 1896, but was not recorded at the Patent Office until January 5 , 1898. See Liber V-56, p. 322, Records of the Patent and Trademark Office, Record Group 241, National Archives.

${ }^{39}$ New York Times, 24 Nov. 1897, p. 2, and 18 Sept. 1898, p. 10; Moley 1967, 57.
} 
had established their expertise in the community, as when Brush secured backing for the Linde Air Products Company simply by assuring local businessmen of the merits of the technology. In addition, association with a hub enterprise such as Brush could in and of itself be a means of attracting both attention and funds. Thus Knight and Bentley's very visible association with Brush Electric enabled them to raise venture capital as far away as New York.

The wealthy Clevelanders who bought shares in these new high-tech enterprises seem to have been motivated by the returns they expected to earn from owning and holding them rather than by the profits they could reap by selling them off after an initial run-up in price. Although a few investors cashed out their investments relatively early (as Lawrence did when he sold off his Brush stock), this practice seems to have been quite uncommon. A search of Cleveland newspapers indicates, for example, that from the time of the formation of the Brush Electric Company until the late 1880 s, when the idea of selling or merging the firm was beginning to be discussed, the only mention of Brush shares available on the market occurred around the time Lawrence was selling out. ${ }^{40}$ Before the formation of the Cleveland Stock Exchange in 1900, the only firms associated with the Brush hub for which share prices were quoted in the Cleveland papers were Brush Electric itself and the Walker Manufacturing Company. Even after the formation of the exchange, we do not see much trading in the equities of concerns associated with this hub. The one major exception, National Carbon, was listed on the exchange from the very beginning, but it was by that time a consolidation of a large number of previously competing firms.

This is not to say that formal financial institutions played no role in the financing of these firms. Once enterprises associated with the hub got off to a good start, they were undoubtedly able to tap into other sources of finance, particularly trade credit from suppliers but also short-

\footnotetext{
${ }^{40}$ Cleveland Plain Dealer, 3 Jan. 1882, p. 8.
} 
term commercial loans from banks and other financial intermediaries. Here the overlapping network of financiers was likely to have played an important role. Some of the men who invested their savings in the new firms were also officers and directors of banks. For example, James J. Tracy, one of the original incorporators of Brush Electric, became vice president of the Society for Savings after a long career in various other Cleveland financial institutions. ${ }^{41}$

Similarly, Myron T. Herrick, a member of the Sperry Syndicate and one of the initial investors in National Carbon, was secretary-treasurer and then president of the Society for Savings, a founder of the Euclid Avenue National Bank, a director of the American Exchange National Bank, and a director of the Garfield Savings Bank. ${ }^{42}$ Some of the inventors and other businessmen involved in these startups and spinoffs also helped to organize financial institutions during this periodBrush himself was a founder and vice president of the Euclid Avenue National Bank (Eisenman 1967, 162) — and it is likely that they did so because they thought their companies would benefit. In addition to providing short-term commercial credit, financial intermediaries could help these firms raise additional capital by underwriting and marketing their bond issues. Thus the Cleveland Trust Company underwrote securities for many local firms, ranging from small electrical manufacturing companies to local telephone companies to larger electrical utilities. ${ }^{43}$ Moreover, in the absence of an active securities market, banks and other financial intermediaries could make investments in equities more liquid by accepting the shares as collateral for loans. The portfolio of the Fairmount Savings Bank, for example, included a number of loans based on such securities. Of the nearly 150 loans approved by the bank from July, 1903, to November,

41 “"Tracy, James Jared, Sr.,” Encyclopedia of Cleveland History; Orth 1910, Vol. 3, 44-5.

42 "Herrick, Myron Timothy," Encyclopedia of Cleveland History; "Ohio Governors."

${ }^{43}$ Reports of the Cleveland Trust Company's Trust Department, 1903-1906, Ameritrust Corporation Records. Unfortunately, this record book is too late to pick up startups and spinoffs that came out of the Brush hub. 
1904, approximately 20 percent were backed by equities, of which about 50 percent were issued by manufacturing enterprises, including the Adams Bagnall Electric Company. ${ }^{44}$

\section{Beyond Brush}

In Cleveland, the Brush Electric Company was one of the earliest and most important examples of an enterprise around which extensive overlapping networks of inventors and financiers formed. But it was not the only such hub. The city's hardware dealers served a similar function, for example. Because their stores were gathering places for people who made and bought the vast variety of products that they stocked, these merchants were particularly well placed to obtain information about new products and production processes, as well as to attract investors for new ventures. One reason why Jacob Cox, founder of the Cleveland Twist Drill Company, decided to move his business to the city was that he was already "well acquainted with the principal hardware dealers in Cleveland, George Worthington \& Company, and Wm. Bingham \& Company, and also with some of the bankers" (Cox 1951, 87). Although it is not certain that Cox himself obtained any advantage from these connections, Worthington and Bingham were in fact major investors in Cleveland industry. Worthington had founded the Cleveland Iron Company in 1849, and he and Bingham together organized the Cleveland Iron and Nail Works in 1863. Bingham's son, Charles W., who was trained in geology, mining, and chemistry, later organized one of Cox's major competitors, the Standard Tool Company, as well as the Parrish \& Bingham Company, a producer of bicycle parts. ${ }^{45}$ Similarly, two of the founders of the Cleveland Cap Screw Company, the acorn from which TRW ultimately grew,

\footnotetext{
${ }^{44}$ Journal of the Finance Committee of the Fairmount Savings Bank (1903), Ameritrust Corporation Records. Again, the extant record book is really too late to pick up enterprises associated with the Brush hub. 45 "Bingham, Charles W.," "Bingham, William," and "Worthington, George," Encyclopedia of Cleveland History; Rose 1950, 217; Fogarty, Garofalo, and Hammack n.d., 3; Cox 1951, 112.
} 
came out of the hardware business. David J. Kurtz and Samuel M. Mathews had in the course of their business learned about a new electric welding technology invented by Elihu Thomson of Lynn, Massachusetts. They envisioned that it would enable them to reduce dramatically the cost of manufacturing cap screws in standard sizes, organized a company to license and exploit the technology, and, through their local connections, were able to raise about $\$ 80,000$ in capital by selling equity in the proposed venture. They were not able to make the enterprise a success, however, until Cleveland automaker Alexander Winton, an early investor, bought control of the company and used the technology to produce engine valves for his cars (Dyer 1998, 17-27).

As this last example suggests, downstream (or upstream) businesses could also be important sources of finance for new ventures. Their assistance to entrepreneurs was likely to be especially critical in technologically advanced industries because they had the expertise as well as the motive to search out promising new prospects. For example, Alexander E. Brown and other entrepreneurs associated with the Brown Hoisting Machine Company provided most of the capital for the Elwell-Parker Electric Company of America in 1893. Brown had been looking for an electric motor capable of driving his ore-handling machinery, discovered the ElwellParker Company in Britain, and arranged for the formation of a company to produce the motor in Cleveland. The new firm was hit badly by the Panic of 1893 and the ensuing depression, but orders from Brown kept the company going (Brown even provided it with production space). In the meantime, Elwell-Parker was able to develop the new product lines (for example, motors for electric automobiles and trucks) that allowed it to expand its customer base and move into a new factory of its own (Rose 1950, 546, 595-6). ${ }^{46}$

\footnotetext{
${ }^{46}$ Brown himself was originally connected with the Brush hub. Born in 1852, he attended Brooklyn Polytechnical Institute in the early 1870 s and then took a job from 1873-74 as chief engineer with the Massillon (Ohio) Bridge Company. While in the company's employ, he invented a method of using scrap iron and steel to build bridge columns. Returning to Cleveland, he attempted to pursue a career as an inventor, in part by working
} 
A more important example, the White Sewing Machine Company, not only assisted upstream producers but became a source of spin-off enterprises rivaling those of Brush. Founder Thomas H. White had moved his small sewing-machine company to Cleveland in the late 1860s, and, in combination with Howard W. White (his half-brother) and Rollin C. White (no relation), formed what later became known as the White Sewing Machine Company. ${ }^{47}$ Once the firm was well established, White began to encourage vertically related ventures. For example, White played a major role in convincing the fledging precision machine-tool firm of Warner and Swasey to move from Chicago to Cleveland. White helped the two partners find a suitable location for their shop, fed them information about potential customers, and assured them that "If anyone undertakes to squeeze you, let me know, and I will see that they don't." He also stepped forward when they needed a respected businessman to guarantee a contract. ${ }^{48}$ White played an even more important role in the success of Theodor Kundtz's furniture company, providing financing backing as well as buying the major part of his output. At that time, sewing-machine furniture consisted of little more than tables on which the machines were bolted. With White's

with in the shop of arc-lighting pioneer Charles F. Brush. Alexander's father, Fayette Brown, was a prominent Cleveland merchant banker, iron dealer, manufacturer, and inventor. When Alexander patented his first hoisting machine, Fayette recognized the value of the invention and financed the formation of a company to exploit it in 1880. "Brown, Alexander Ephraim" and "Brown, Fayette," Encyclopedia of Cleveland History; "Brown, Fayette," Dictionary of American Biography; Rose 1950, 437-8.

47 "Register"; and White Motor Company, "Important Milestones in White Motor History: Chronological Highlights of Present and Predecessor Organizations (1859-1949)," Container 4, Folder 39, Thomas H. White Family Papers Collected by Betty King, Ms. 4725, Western Reserve Historical Society Manuscript Collections. See also Hritsko 1988, 9-11; Rose 1950, 336; "White, Rollin Charles," and "White, Thomas H.," Encyclopedia of Cleveland History.

${ }^{48}$ See the letters from Thomas H. White to Warner and Swasey dated 12 Jan. 1881, 28 Jan. 1881, 25 May 1881, and 15 June 1881, Box 36, Folder 3; Ambrose Swasey, "Address," 19 May 1920, Box 17, Folder 2; Reminiscences of Worcester R. Warner, 11 Jan. 1927, Box 1, Folder 3, Warner and Swasey Collection, Kelvin Smith Library, Case Western Reserve University. Francis F. Prentiss, one of the partners with Jacob Cox in the firm that became the Cleveland Twist Drill Company, also helped to lure Warner and Swasey to Cleveland. See "Recollections of George D. Phelps," 18 August 1939, Box 20, Folder 7, and letter from Cox and Prentiss to Warner and Swasey, 30 March 1881, Box 36, Folder 3, Warner and Swasey Collection. 
support, Kundtz innovated by designing and patenting convertible tables which, when not in use for sewing, closed up to become attractive pieces of furniture. ${ }^{49}$

Like many other enterprises using machine-tool technology, the White Sewing Machine Company made a number of products over the years besides sewing machines. These included kerosene street lamps, roller skates, phonographs, bicycles, and precision tools. In 1890, the Whites spun off their machine-tool business as a separate concern, the Cleveland Machine Screw Company, headed by Rollin C. White. This firm also diversified its output (Rose 1950, 336). Thomas White's son, Rollin H. White, was a gifted inventor who had double majored in both mechanical and electrical engineering at Cornell. Rollin and his brother Windsor (who also had engineering training) developed a type of "safety bicycle" while working in the Screw Company's employ. The company had acquired a local bicycle stamping concern, the A. L. Moore Company, and it produced the bicycles until it sold off this part of its business to the American Bicycle consolidation in $1898 .^{50}$ As already discussed, Elmer Sperry arranged for the Cleveland Machine Screw Company to produce the electric car he had designed at Brush, assigning the company his patents in exchange for shares of its stock and agreeing to assume the position of electrical engineer. This business, along with Sperry's patents, was sold to American Bicycle in 1900 (Hughes 1971, 88; Hritsko 1988, 12-13; Wager 1986, 221-23).

Around the same time, Walter C. Baker founded his own company to produce the electric vehicles he had designed in a Brush shop. Financial backing for the company came from his father-in-law, Rollin C. White, the president of Cleveland Machine Screw Company. Baker's father, George W. Baker, had been an inventor and long-time employee of the White Sewing

\footnotetext{
${ }^{49}$ Eiben 1994, 13-14, 20-3, 25-6, 48-9; Hritsko 1988, 29; "Kundtz, Theodor," Encyclopedia of Cleveland History; Rose 1950, 529, 693.

${ }^{50}$ Report 3, Alice Lunn to Betty King, 29 Dec. 1990, Container 4, Folder 34, Thomas White Family Papers. See also Hritsko 1988, 13-14.
} 
Machine Company. Walter attended the Case School of Applied Science and after a brief stint as a civil engineer, returned to work at the Screw Company. There he invented a revolutionary anti-friction ball bearing that could be used for bicycles, carriages, and automobiles, and with the assistance of his father-in-law and several other men, organized the American Ball Bearing Company in 1895 , the same year he received his patent. ${ }^{51}$

When Thomas White's son, Rollin H., developed a new kind of flash boiler for steam vehicles in 1899 , the White Sewing Machine Company also added the production of automobiles to its already diversified product line. The vehicles proved so successful that the Whites spun off production into a separate automobile concern, the White Company, in $1906 .{ }^{52}$ Bowing to trends in popular demand, in 1909 the company began producing gasoline vehicles, the main components of which were designed by other companies, and began to phase out the production of steam cars in 1911. Forced to spend more of his time simply managing production, Rollin had comparatively little outlet for his creativity and was stimulated by a visit to a Hawaiian plantation owned by another brother, Clarence, to turn his energies toward designing agricultural equipment. He invented the first crawler-type tractor and, with Clarence's help, founded the Cleveland Motor Plow Company in 1916 (later renamed the Cleveland Tractor Company and shortened to Cletrac). Once Cletrac's success was assured, he founded another car company, the

${ }^{51}$ Orth 1910, Vol. 2, 332-32; "The Baker Motor Vehicle Company," Men of Ohio 1914; Wager 1986, 20518; "The Baker Materials Handling Co." and "Baker, Walter C.," Encyclopedia of Cleveland History.

${ }_{52}$ According to Hritsko (1988, 13-19), Thomas H. White bought a steam car from Locomobile in 1899 and gave Rollin H. responsibility for maintaining it. Frustrated by the unreliability of the car's engine, Rollin developed an improved boiler and offered to sell his invention to Locomobile. When the Locomobile refused to buy it, the Whites decided to develop their own car. See also White Motor Company, "Important Milestones in White Motor History"; "Twenty Years of Knowing How: Tracing the Development of The White Company and its Product Through Two Decades of Transportation Achievement," The Albatross, 9 (1921), pp. 4-5, in Container 4, Folder 39, Thomas H. White Family Papers; Richard 1986, 53-60; Rose 1950, 620; "White, Rollin Henry," Encyclopedia of Cleveland History. 
Rollin Motor Company, in 1923. That venture lasted only a few years, though it the cars it produced embodied notable technological advances. ${ }^{53}$

By the time these latter enterprises were organized, the formal financial institutions that Cleveland's industrialists had helped to create were more accessible to new high-tech startups and spinoffs. The Whites' automobile venture, for example, was listed on the Cleveland Stock Exchange in 1912— just six years after its formation. Nonetheless, the role played by such institutions in the creation and promotion of new firms was still relatively minor. As in the case of the firms associated with the Brush hub, early investment still came primarily through local informal channels. Family and friends played a prominent role, as did upstream or downstream enterprises who had special reasons to encourage the development of complementary businesses. Other significant amounts came from business people in the local community who were eager to follow the example of those who had gotten rich from investing in cutting-edge technologies.

Such local business people were only willing to invest, however, if they had good reason to believe that the new ventures seeking their funds were likely to be profitable. Well known inventors such as Sperry could readily attract capital because they had established reputations for generating economically significant technologies. Inventors who were just starting their careers needed some other way to signal that their ideas were promising. Here Cleveland's industrial hubs played a critical role. Because they were collecting points for technological expertise, they served an important vetting function. Inventors seeking validation for their ideas gravitated to these hubs. So did business people in search of profitable investments. In this way, the networks that formed around innovative firms like Brush Electric and White Sewing Machine became

${ }^{53}$ Letters from Henry Merkel to Betty King, 4 Jan. 1991 and 14 Jan. 1991; Report 3, Alice Lunn to Betty King, 29 Dec. 1990; Report 10, Alice Lunn to Betty King, 11 March 1991; and photocopy, "28 Years of Constant Improvement Behind Cletracs," Container 4, Folder 34, Thomas White Family Papers; Hritsko 1988, 45, 49-50; Wager 1986, 63-66, 186-8; Rose 1950, 730. 
engines of local economic development. They encouraged the geographic concentration both of technological creativity and of venture capital. They also matched inventors who had promising ideas with business people who possessed the managerial skills needed to transform these ideas into productive enterprises.

\section{References}

Anderson International Corp. n.d. "History of Anderson." http://www.feedscrews.com/supplierview.php?sid=1017.

Anonymous. 1927. Biography of Alfred Hutchinson Cowles, Sewaren, New Jersey: Scientist, Inventor, Economist. Pioneer in the Aluminum Process and in Electric Smelting. New York: The Writers Press Association.

Brush, Charles F. 1905. “The Arc-Light.” Century Illustrated Monthly Magazine, 70 (May): $110-18$.

Case Western Reserve University Library. 1914. Men of Ohio. Originally published by the Cleveland News and the Cleveland Leader. http://www.cwru.edu/UL/DigiLib/CleveHist/MenOfOhio/Men.html.

Cayahoga County, Ohio, Genealogy and History. n.d. Naturalization Records, 1818-1931. http://www.rootsweb.com/ ohcuyah2/nats/coarch/part4/pg0246.html.

Cleveland Plain Dealer. Various Issues.

Cleveland Stock Exchange Handbook. Various Issues.

Cooper, Hal D., and Thomas M. Schmitz. 1993. A History of Inventions, Patents and Patent Lawyers in the Western Reserve. Cleveland: Cleveland Intellectual Property Law Association. 
Covington, Edward J. 1999. Incandescent Lamp Manufacturers in Cleveland, 1884-1905.

Cleveland: privately printed.

Cowles, Alfred. 1958. The True Story of Aluminum. Chicago: Henry Regnery Company.

Cox, Jacob Dolson Sr. 1951. Building an American Industry: The Story of The Cleveland Twist Drill Company and Its Founder. Cleveland: The Cleveland Twist Drill Company.

Croly, Herbert David. 1965. Marcus Alonzo Hanna: His Life and Work. 1912 edn.; Hamden, Conn.: Archon Books.

Dawson, Virginia P. 1999. Lincoln Electric: A History. Cleveland: Lincoln Electric Company.

Dictionary of American Biography.

Dun, R. G. \& Company. 1910.

Dyer, Davis. 1998. TRW: Pioneering Technology and Innovation since 1900. Boston: Harvard Business School Press.

Eiben, Christopher J. 1994. Tori in Amerika: The Story of Theodor Kundtz. Cleveland: Ewald E. Kundtz, Jr.

Eisenman, Harry J. 1967. "Charles F. Brush: Pioneer Innovator in Electrical Technology.” Unpublished Ph.D. dissertation, Case Institute of Technology.

Fogarty, Michael S., Gasper S. Garofalo, and David C. Hammack. n.d. Cleveland from Startup to the Present: Innovation and Entrepreneurship in the $19^{\text {th }}$ and Early $20^{\text {th }}$ Centuries. Cleveland: Center for Regional Economic Issues, Weatherhead School of Management, Case Western Reserve University.

Gorman, Mel. 1961. "Charles F. Brush and the First Public Electric Street Lighting System in America." Ohio Historical Quarterly, 70 (April): 128-44. 
Hansler Industries, Ltd. n.d. “Company Information.” http://www.hansler.com/hi/info.html.

Hritsko, Rosemary Solovey. 1988. "The White Motor Story." Unpublished Ph.D. dissertation, University of Akron.

Hughes, Thomas Parke. 1971. Elmer Sperry: Inventor and Engineer. Baltimore: Johns Hopkins Press. 1989. American Genesis: A Century of Invention and Technological Enthusiasm. New York: Penguin.

Hunsaker, J. C. 1955. Biographical Memoir of Elmer Ambrose Sperry, 1860-1930. Washington: National Academy of Sciences.

“John W. Seaver." 1911. Journal of the Cleveland Engineering Society. 3 (March): 69-70.

Kennedy, J. H. 1885. "The Brush Electric Light—The History of a Cleveland Enterprise." Magazine of Western History, 3 (Dec.), pp. 132-48.

Lamoreaux, Naomi R., and Kenneth L. Sokoloff. 1999a. "Inventors, Firms, and the Market for Technology in the Late Nineteenth and Early Twentieth Centuries." In Learning by Doing in Markets, Firms, and Countries, ed. Naomi R. Lamoreaux, Daniel M. G. Raff, and Peter Temin. Chicago: University of Chicago Press. Pp. 19-60. . 1999b. "Inventive Activity and the Market for Technology in the United States, 18401920.” NBER Working Paper 7107. . 2002. "The Decline of the Independent Inventor: A Schumpeterian Story?" Unpublished paper. . 2003. "Intermediaries in the U.S. Market for Technology, 1870-1920." In Finance, Intermediaries, and Economic Development, ed. Stanley L. Engerman, et al. New York: Cambridge University Press. Pp. 209-46. 
2004. "The Market for Technology and the Organization of Invention

in U.S. History." In Entrepreneurship, Innovation and the Growth Mechanism of the Free-Market Economies, ed. Will Baumol and Eytan Sheshinski. Princeton: Princeton University Press.

Linde Lift Truck Corporation. n.d. "Our History.” http://www.lindelifttruck.com/history.htm. Los Angeles Times. Various issues.

Men of Ohio. 1914. Cleveland: Cleveland News and Cleveland Leader. http://www.cwru.edu/UL/DigiLib/CleveHist/MenOfOhio/Men.html.

Miller, Carol Poh, and Robert Wheeler. 1990. Cleveland: A Concise History, 1796-1900. Bloomington: Indiana University Press.

Moley, Raymond. 1962. The American Century of John C. Lincoln. New York: Duell, Sloan and Pearce.

National Malleable and Steel Castings Co. 1943. National Malleable and Steel Castings Company: $75^{\text {th }}$ Anniversary, 1868-1943. Cleveland: privately printed.

New York Times. Various issues.

"Ohio Governors." n.d. Ohio Historical Society. http://www.ohiohistory.org/onlinedoc/ohgoverment/governors/.

Orth, Samuel P. 1910. A History of Cleveland, Ohio. Chicago: S. J. Clarke. 3 Vols.

Rose, William Gansom. 1950. Cleveland: The Making of a City. Cleveland: World Publishing Company.

Schlesinger, Carl, ed. 1989. The Biography of Ottmar Mergenthaler: Inventor of the Linotype. New Castle, Del.: Oak Knoll Books. 
Sicilia, David B. 1989. "Samuel Thomas Wellman.” In Encyclopedia of American Business History and Biography: Iron and Steel in the Nineteenth Century, ed. Paul F. Paskoff. New York: FactsOnFile. Pp. 359-63.

Short, S. H. 1899. “The First Electric Railroad.” Los Angeles Times (14 May), p. 28.

Smith, S. Winifred. 1955. "Sidney Howe Short.” Museum Echoes, 28 (October), pp. 75-77.

“Some EV History." n.d. http://www.econogics.com/ev/evhistb.htm.

Stockly, George W. 1901. "Some Early Arc Lighting Experiences.” Electrical Review, 38 (12 Jan.), p. 66.

U.S. Census Office. Statistical View of the United States ... Compendium of the Seventh Census (1850). Table "Statistics of Ohio," pp. 290-5.

U.S. Census Office. Manufactures of the United States in 1860. Table 1, "Manufactures, by Counties, 1860," pp. 447-8.

U.S. Census Office. The Statistics of the Wealth and Industry of the United States (1870), vol. III, Table XI, “Selected Statistics of Manufactures pp. 712-3.

U.S. Census Office. Report on the Manufactures of the United States at the Tenth Census (June 1, 1880 (vol. 2, Table 5 "Selected Statistics of Manufactures”, pp. 322-3).

U.S. Census Office. Compendium of the Eleventh Census: 1890 (Part II, Table 2, "Manufactures in 165 Cities having a population of 20,000 and over, by specified industries: 1890," p. 782-5).

U.S. Census Office. Census Reports (1900) (vol. VIII, Table 8 "Manufactures in Cities by Specified Industries," pp. 710-3). 
U.S. Bureau of the Census. Thirteenth Census of the United States ...Volume IX Manufactures (Table I, “Comparative Summary for 1909, 1904, and 1899 - Cities of 50,000 inhabitants or more - all industries combined and selected industries, pp. 976-978).

U.S. Bureau of the Census. Fourteenth Census of the United States 1920 ... Volume IX Manufactures (Table 46, p. 1202-3).

University of Virginia Geospatial and Statistical Data Center. United States Historical Census Data Browser. ONLINE. 1998. University of Virginia. Available: http://fisher.lib.virginia.edu/census/. Inter-University Consortium for Political and Social Research. Study 00003: Historical Demographic, Economic, and Social Data. Ann Arbor: ICPSR.

Van Tassel, David D., and John J. Grabowski, comp. Encyclopedia of Cleveland History. http://ech.cwru.edu/.

Wager, Richard. 1986. Golden Wheels: The Story of the Automobiles Made in Cleveland and Northeastern Ohio, 1892-1932. $2^{\text {nd }}$ edn. (corrected): John T. Zubal, Inc.

Wall Street Journal. Various issues.

Wellman, S. T. 1902. “The Early History of Open-Hearth Steel Manufacture in the United States." Transactions of the American Society of Mechanical Engineers, 23 (1902), pp. 78-98.

Wellman Engineering Co. 1956. A Report on the Public Commemoration of the $68^{\text {th }}$ Anniversary. Cleveland: privately printed. 


\section{Appendix: Cleveland Inventors, 1900 Sample}

Anderson, Valerius D. 13 patents in sampled years, no assignments at issue. Nearly all of the patents were for "presses" designed to extract oil from seeds. Was a principal in a firm that bore his name but did not assign to it at issue.

1897-8 Cleveland Directory: president and treasurer of the V. D. Anderson Co. 1906-7 Directory: not listed.

Anderson was born around 1830. His work history begins in 1855 in a tin shop in Milton, Wisconsin, that made hoops for skirts and repaired tin roofs. He moved to Kewanee, Illinois, invented and patented a steam boiler, and formed a company to commercialize his invention. He next moved to Springfield, Ohio where he managed the Mast-Foos Company, a boiler manufacturer, that was later acquired by International Harvester. Anderson left Mast-Foos in 1876. In 1880 he moved to Cleveland, where he invented a rendering tank for use by butchers. "Sales of these tanks dropped when packinghouses started to replace butcher shops, causing Mr. Anderson to develop and turn to the manufacture of fertilizer dryers." He ran the business out of his home, where he was assisted by two of his sons and two younger brothers. In 1888 he founded the V. D. Anderson Company, and in 1893 the company moved into a small factory on the west side of Cleveland. Among his most important inventions was a steam trap in 1893 (which "not only made his fertilizer dryer the most efficient, but also expanded his market into steam specialties around the world") and a press for extracting oil from seeds (or degreasing the cooked byproducts of butchers) that the company commercialized itself (Anderson International Corp. n.d.; Rose 1950, 440-41).

Avery, Henry C. 10 patents in sampled years. Assignee at issue: Avery Stamping Company (1 patent in 1899, 2 in 1902, 3 in 1905-retained share of the 3 in 1905). Most of his patents dealt with railway ties, but he also patented designs for "non-refillable receptacles" and for a "pneumatic tire." Was a principal in a firm that bore his name and assigned most of his patent to it at issue.

1897-8 Cleveland Directory: secretary and manager of the Avery Stamping Company. 1906-7 Directory: not listed.

Baker, Walter C. 8 patents in sampled years. Assignees at issue: American Ball Bearing Machine (one patent in 1898). His patents covered designs for antifriction bearings, grinding machines, motor vehicles, a voltmeter, a transmission for automobiles, and a cloth-cleansing device. Was a principal in a firm that bore his name and also in another company formed to exploit his inventions, but did not assign most of his patents to these firms at issue.

1897-8 Cleveland Directory:

1906-7 Directory:

Baker was born in Hinsdale, New Hampshire, in 1868 and moved to Cleveland with his parents at the age of three. His father, George W. Baker, was an inventor and long-time 
associate of the White Sewing Machine and Cleveland Machine Screw Companies. Walter attended Case School of Applied Science, graduating in 1891. That same year he married Fannie Elizabeth White, daughter of Rollin C. White, one of the founders of the White Sewing Machine Company and president of Cleveland Machine Screw, where Baker went to work after a stint as a civil engineer. In 1893 Baker helped establish his reputation by exhibiting his "Electrobat," a light electric vehicle equipped with bicycletype wheels, at the Chicago Exposition. Around the same time, Baker invented a revolutionary anti-friction ball bearing that could be used for bicycles, carriages, and automobiles, and with the assistance of his father-in-law and several other men, organized the American Ball Bearing Company in 1895, the same year he received his patent. Baker became president of the new company, which produced axles for horsedrawn vehicles and then for automobiles, and served in that capacity until 1918, when the firm merged with thirteen other concerns to form the Standard Parts Company (Baker stayed on as consulting engineer). In 1897 Baker built an electric automobile with F. Philip Dorn, secretary of the Ball Bearing Company. The two men worked on the car in a building at the Brush Electric Company shop, where their friend Elmer Sperry was also developing an electric car. While Cleveland Machine Screw geared up to produce Sperry's vehicle, Rollin C. White and his son, Fred R. White, left to help Baker and Dorn organize the Baker Motor Vehicle Company in 1898. Baker held the post of vice president and mechanical engineer of that company until 1906, when he gave up his formal position in order to concentrate his energies more fully on the Ball Bearing Company. Baker was also a director of the Peerless Motor Car Company and helped engineer that company's cars. He was an extraordinarily talented inventor who counted Thomas Edison among his friends (Edison bought his first electric car). Later Baker worked with Lee DeForest on the development of amplifiers for radio. (Orth 1910, Vol. 2, 332-32; "The Baker Motor Vehicle Company," Men of Ohio 1914; Wager 1986, 20518; “The Baker Materials Handling Co." and "Baker, Walter C.," Encyclopedia of Cleveland History; Hansler Industries n.d.; "Some EV History” n.d.; Linde Lift Truck Corporation n.d.).

Ball, Herman F. 6 patents in sampled years. Assignee at issue: Chicago Railway Equipment Company (one patent in 1898). His patents included designs for a "brakebeam," a car buffer, and a key for a journal box. Was an employee but did not assign his inventions at issue.

1897-8 Cleveland Directory: general car inspector for the L.S. \& M.S. Railway Co. 1906-7 Directory: no occupation listed

Brown, Alexander E. 17 patents in sampled years. Assignees at issue: Brown Hoisting Machinery Company (assigned to this company all patents except 2 in 1899 and 1 in 1900). Virtually all of his patents related to hoisting. Was a principal in a firm that bore his name and assigned most of his patents at issue to the firm.

1897-8 Cleveland Directory: vice president and general manager of the Brown Hoisting \& Conveying Machine Co.

1906-7 Directory: same 
Alexander E. Brown was born in Cleveland in 1852. He father, Fayette Brown, was a private banker and iron dealer. A graduate of Central High School, Alexander studied civil engineering at Brooklyn Polytechnic Institute in 1872. He worked as chief engineer at the Massillon, Ohio Bridge Company in 1873-4, where he developed a method of using scrap iron and steel to build bridge columns. He then returned to Cleveland and pursued a career as an inventor (in part by working on lamps along with Charles F. Brush). He invented a hoist that partially automated the unloading of cargo at Great Lakes ports. With his father, he organized the Brown Hoisting \& Conveying Machinery Company in 1880 with a capital of $\$ 100,000$. They incorporated the firm in 1893. Also in 1893 the Browns organized the Elwell-Parker Electric Company of America to supply the hoisting firm with electric motors. He died in 1911 (Rose 1950, 437-8, 546; "Brown, Alexander Ephraim," Encyclopedia of Cleveland History).

Brown, Fayette. 1 patent in sampled years, not assigned at issue. Patent was for 'counterbalancing mechanism for floating derricks'. Was a principal in a firm that bore his name and also in other companies. Was a "Great Inventor," most of whose patents were outside the sample period.

1897-8 Cleveland Directory: member of the partnership Harvey H. Brown \& Co., agents and dealers in iron ore and pig iron (H. H. Brown was his son) and president of the Brown Hoisting \& Conveying Machine Company.

1906-7 Directory: same

Fayette Brown was born in North. Bloomfield, Ohio, in 1823, the youngest of nine children. His father, Ephraim, had joined with a friend to purchase that township, moved there from New Hampshire, and became a leader in this "transplanted New England Community." At 18, after finishing his education in local public schools, he worked in Pittsburgh for his brother's wholesale dry-goods firm, becoming a partner in 1845 . He moved to Cleveland in 1851 and formed a banking partnership with George Mygatt (Mygatt \& Brown), taking over the business when Mygatt retired in 1857 . He closed the business and became a U.S. Army paymaster in 1861. He resigned his commission in 1862 and returned to Cleveland as general manager and agent of the Jackson Iron Company. He remained in that position for the next 25 years. During that period he secured four patents dealing with blast furnaces (issued in 1884 and 1885). He also became interested in Great Lakes shipping and invested in a fleet of lake steamers for transporting iron ore. In 1880, he organized Brown Hoisting Machinery Company in 1880 to exploit the inventions of his son, Alexander E. Brown (see above). Fayette served as president of that company until his deat in 1910. He also served as president of the Union Steel Screw Co., the National Chemical Company, and the G. C. Kuhlman Car Company; as general manager of the Stewart Iron Co. of Sharon, Pennsylvania; and as receiver of the Brown, Bonnell Co. of Youngstown, Ohio (Dictionary of American Biography; "Brown, Fayette," Encyclopedia of Cleveland History; Rose 1950, 437-8; Orth 1910, Vol. 3, 429-31). 
Burnham, Frank A. 7 patents in sampled years, all assigned at issue to the Chandler and Price Company. The patents pertained to printing presses and milling machines for paper. Was an employee of the firm to which he assigned his inventions at issue.

1897-8 Cleveland Directory: superintendent of the Chandler and Price Company. 19067 Directory: not listed

Champ, Joseph $[\mathrm{H}] .8$ patents in sampled years. Assignee at issue: Bishop \& Babcock Company ( 2 in 1898 and 2 in 1900). Patents were for fluid pressure regulators, tire inflators, a coincontrolled apparatus, and an "implement for imparting vibratory devices." He was an employee and then a principal in the firm to which he assigned his patents at issue.

1897-8 Cleveland Directory: vice president of the Bishop \& Babcock Company, which owned the Cleveland Mfg. Co. and Cleveland Tack Works, producers of faucets, pumps, brass goods, tacks and nails.

1906-7 Directory: same

Champ was born in Cleveland in 1857. His parents were British immigrants. He attended public schools and then, in 1873, began learning the plumbing trade. He obtained a job with Bishop and Babcock, manufacturers of air pumps, brass goods, and tacks and nails in 1880 and was promoted to partner and general superintendent in 1890 . He became vice president and general manager the Bishop \& Babcock Company in 1895. He also became president of the Julier Baking Company in 1902, remaining a director when he resigned that position in 1906. He served as a director of the Standard Welding Company and organized the Cleveland Savings Bank, serving as its president for one year (Orth 1910, Vol 2, 185-6).

Cleveland, William B. 4 patents in sampled years, no assignments at issue. Patents were for "forming electrical connections" and a "valve for hydraulic presses." Was a principal in a company, but did not assign his patents to it at issue.

1897-8 Cleveland Directory: president of Forest City Electric Company 1906-7 Directory: same

Coffin, Walter E. 5 patents in sampled years, all assigned at issue to National Malleable Castings Company. Patents were for car couplings and a "draftbar attachment." Was an employee of the firm to which he assigned his inventions at issue.

1897-8 Cleveland Directory: salesman

1906-7 Directory: salesman for National Malleable Castings Co.

Coffin began to work for National Malleable Castings in 1896. He was a pioneer developer of railroad specialties for the company and later Consulting Engineer to its Railroad Department (National Malleable Castings 1943, 10).

Cowles, William B. 11 patents in sampled years, 1898-1907. Assignees at issue: Long Arm System Company (1 patent in 1898, 1 in 1899, 1 in 1902, 1 in 1903, 2 in 1906, and 1 in 1907); 
Cleveland Trust Co, trustee (1 in 1903). Patents were generally for bulkhead doors and various systems for opening and closing them. Was a principal in a company and assigned most of his patents at issue to it.

1897-8 Cleveland Directory: architect.

1906-7 Directory: vice president of the Long-Arm System Co.

Dun Lany [Dunlany], William P. 3 patents in sampled years, all joint with H. R. Palmer. Assignee at issue: International Fac-Similegraph Company (1 patent in 1900). Patents were for a facsimile telegraph and a "marking machine." Appears to have invented as a side line and was not connected with his assignee.

1897-8 Cleveland Directory: doctor 1906-7 Directory: not listed

Eastwood, Arthur C. 34 patents in sampled years. Assignee at issue: Electric Controller and Supply Company (1 patent in 1900, 5 in 1902). Patents were for an electric motor, magnetic clutch, "motor starting," "motor controlling," and a controller for electric motors. Was a principal in a firm and assigned a small proportion of his patents to the firm at issue.

1897-8 Cleveland Directory: not listed

1906-7 Directory: vice president of Electric Controller and Supply Co.

Edson, Eugene R. 29 patents in sampled years. Assignees: Buckeye Fish Company (4 patents in 1900); Edson Reduction Machinery Company (1 in 1902, 6 in 1903, 2 in 1905). Patents were for reducing and rendering fish or other material, making gelatin, extracting oil, and disposing of foul odors. Was a principal in a firm that bore his name and assigned some of his patents at issue to it.

1897-8 Cleveland Directory: president of the E. R. Edson Co. (fish) 1906-7 Directory: president of the Edson Reduction Machinery Co.

Gilbert, Charles L. 3 patents in sampled years, none assigned at issue. Patents included designs for a traveling bag and a telescope case. Appears to have invented as a side line and did not assign at issue.

1897-8 Cleveland Directory: two listings — an agent and a cashier at the Erie Railroad freight depot

1906-7 Directory: two listings, one for a cashier and one for a "coml trav."

Hall, James R. 6 patents in sampled years, none assigned at issue. Patents included designs for a fish hook, bait bucket, paint can, and water heating apparatus. Appears to have invented as a side line and did not assign at issue.

1897-8 Cleveland Directory: retired

1906-7 Directory: not listed 
Jeavons, William R. 16 patents in sampled years, 1899-1907. Assignee at issue: United Blue Flame Stove Company (2 in 1899). Patents included designs for a burner, a hydrocarbon burner, and an oil burner. Was an employee but appears not to have assigned his patents at issue (or at least not most of them) to his employer.

1897-8 Cleveland Directory: superintendent.

1906-7 Directory: supervisor at the Cleveland Foundry Co.

Kundtz, Theodor. 13 patents ( 3 co-patented with others who assigned their shares to him) in sampled years, none assigned at issue. Patents included designs for sewing machine cabinets and tables for sewing machines. Was a principle in a firm that bore his name but did not assign his patents at issue to it.

1897-8 Cleveland Directory: manufacturer of sewing machine cabinets 1906-7 Directory: Sewing Machine Cabinet Works

Kundtz was born in Metzenseifen, Austria-Hungary, in 1852 and migrated to the U.S. and to Cleveland in 1872 at the age of 20. His first job was with a small woodworking firm (the Whitworth Co.) that made sewing machine cabinets. The owner went bankrupt after a damaging fire. Kundtz and three other employees (George Gebbard, Charles Simon, and Edward Genee) bought the remaining assets and started the Cleveland Cabinet Co. One by one Kundtz bought out his partners until he was the sole proprietor of the Theodor Kundtz Cabinet Work by 1878. He supplied all the cabinets for the White Sewing Machine Co. As the business grew, Kundtz expanded into new products from school desks to church pews to bicycle wheels, many of which were based on his own inventions. Later he also built automobile bodies for the Whites. By 1910, Kundtz headed a vertically integrated enterprise that employed 2500 workers in five plants and was the largest consumer of hardwood in the state of Ohio. He died in 1937 (Eiben 1994, 13-14, 20-3, 25-6, 48-9; "Kundtz, Theodor," Encyclopedia of Cleveland History; Rose 1950, 529, 693).

Long, Timothy. 5 patents in sampled years. Assignee at issue: Browning Engineering Company (1 patent in 1902). Patents include designs for a car-dumping apparatus, a hoisting and conveying machine, and a Merry Go Round. Cannot tell whether was employee or independent, but if he worked for a firm he did not assign the bulk of his inventions to it at issue.

1897-8 Cleveland Directory: machinist

1906-7 Directory: Timothy F. Long was a machinist

Morris, William L. 14 patents in sampled years, 1898-1905. Assignees at issue: Austin Cartridge Company (1 patent in 1898, 2 in 1899, 2 in 1900, 1 in 1902, and 1 in 1905); N. Bellers of Bernie, MO (share of a patent in 1899). Patents include designs for a "shell-loading machine," "cartridge loading," "churn motor," "tree protector," "printing device," and "apparatus for punching gun wads." Was an employee and then perhaps independent but did not assign his patents at issue to his employer. 
1897-8 Cleveland Directory: superintendent for J. F. Randall (steam engineering, mill architect, electric lighting and electric railway plants)

1906-7 Directory: mechanical engineer

Neuhs, Werner. 4 patents in sampled years. Assignee at issue: W.E. Krumsoy (share of a patent in 1898). Patents include devices such as a flat iron, baker's oven, and smoke preventing device for furnaces. Was an employee at least by 1906-7, but there's no indication that he assigned to his employer at issue.

1897-8 Cleveland Directory: bricklayer.

1906-7 Directory: superintendent

Palmer, H. R. 3 patents in sampled years, all joint with William P. Dun Lany [Dunlany].

Assignee at issue: International Fac-Similegraph Company (1 patent in 1900). Patents were for a facsimile telegraph and a "marking machine."

1897-8 Cleveland Directory:

1906-7 Directory:

Potter, John A. 14 patents in sampled years, none assigned at issue. Patents were for a forging press, casting apparatus, and for iron and steel manufacturing generally. Was a principal in a company but did not assign to it at issue.

1897-8 Cleveland Directory: vice president of the Cleveland Steel Co, manufacturers of steel and copper plates.

1906-7 Directory: not listed

Rogers, John R. 38 patents in sampled years, all of which he assigned at issue to Mergenthaler Linotype Company. Patents were for various types of linotype machines. He was a principal in a firm that bore his name and then an employee of the firm to which he assigned his inventions.

1897-8 Cleveland Directory: not listed

1906-7 Directory: not listed

Rogers was born in 1856 in Roseville, Ill. After attending Berea College in Kentucky and then Oberlin (A.B. 1875), he taught in the Michigan public schools and then at Berea College. From 1877-1881 he was superintendent of schools in Lorain, Ohio. He then did engineering work for the railroads for two years in Iowa and Michigan, returning to Lorain to teach until 1888. He got interested in mechanical type setting, obtained a patent in 1888 for a machine for "making stereotype matrices," and moved to Cleveland, Ohio, where he organized the Rogers Typograph Co. Rogers introduced a typesetting machine in 1890 whose production was enjoined the next year for infringing on Ottmar Mergenthaler's linotype invention. Several years later another of Rogers's inventions involved him in an interference suit with Merganthaler and with another inventor named Jacob W. Schuckers. Rogers bought Schuckers' patent, which was subsequently validated. The Mergenthaler then bought Rogers's firm in 1895, and Rogers went to work 
for the consolidated company (Merganthaler Linotype) in Brooklyn as a consulting engineer and head of the firm's "experimental department." He died in 1934 (Dictionary of American Biography; Schlesinger 1989, 59, 66-68).

Sears, Charles. 13 patents in sampled years, none assigned at issue. All patents related to typewriting. Was a principal of a firm that bore his name but did not assign his patents to it at issue.

1897-8 Cleveland Directory: manager of the Sears Typo-Matrix Co 1906-7 Directory: not listed

Seaver, John W. 26 patents in sampled years, some joint with Wellmans. Assignees at issue: Wellman-Seaver Engineering Company (1 patent in 1898, 4 in 1900, 2 in 1902, and 2 in 1903); Wellman-Seaver-Morgan Engineering Co. (4 in 1903, 2 in 1905, and 1 in 1907). Patents included inventions for a gas producer, shipbuilding crane, furnace filling, blast furnace charging, and ore storage and delivery. Was a principal in a firm that bore his name and to which he assigned many of his inventions at issue.

1897-8 Cleveland Directory: vice president of the Wellman-Seaver Engineering Co. (engineers and contractors, bessemer and open-hearth steel, etc.)

1906-7 Directory: chairman of the board of Wellman-Seaver-Morgan

Seaver was born in Madison, Wisconsin, in 1856 and then moved with his parents to Buffalo, New York. At the age of 13, he took a job in the machine shop of the Shepard Iron Works, attending school in the evenings. Five years later he moved to the Howard Iron Works, which designed and built marine engines. He was promoted to Assistant Superintendent at the age of 20. After a stint in the partnership of Seaver \& Kellogg, where he built the first steel railroad cars in the U.S., be took a position with the Kellogg Bridge Works and then, in 1880, became chief engineer of the Iron City Bridge Works in Pittsburgh. In 1884 he assumed the same title at the Riter-Conley Co. and earned a reputation designing blast furnaces, steel works, oil refineries, and other industrial structures. In 1896 he joined Samuel T. and Charles H. Wellman to found WellmanSeaver Engineering (later Wellman-Seaver-Morgan), assuming the position of vice president. The firm operated extensive plants in Cleveland and Akron, manufacturing ore and coal handling machinery, car dumpers, hoisting engines, water power, steel plant and railroad equipment, and other heavy machinery. He remained a director of that firm until his death in 1911, but in 1906 joined a consulting practice with James E. A. Moore (“John W. Seaver" 1911; "Seaver, John Wright," Encyclopedia of Cleveland History).

Short, Sidney H. 32 patents in sampled years. Assignees at issue: Walker Company of New Jersey (5 in 1899); Westinghouse Electric and Manufacturing Company, Pittsburgh, Pa. (4 in 1900 and 1 in 1902). His patents related to electric motors, railway cars, and electric trolleys. Was a principal in a firm that bore his name and then a principal in Walker Manufacturing Company, to which he assigned five patents. He was neither a principal in nor an employee of his other assignee, Westinghouse. 
1897-8 Cleveland Directory: vice president of the Walker Company (electrical machinery).

1906-7 Directory: deceased

Short was born in Galena, Ohio, in 1858 and grew up in Columbus, where his father was a manufacturer. He developed an early interest in electricity, which he pursued by studying physics at Ohio State. Graduating in 1880, he accepted a professorial position at the University of Denver, where he taught physics and chemistry and pursued research in electrical applications. After demonstrating his invention of electric trolley car, local capitalists organized the Denver Tramway Company to build an electric streetcar in that city. Obtaining a contract for a trolley system in St. Louis, he secured financial backing from an Ohio investor who arranged to have the necessary dynamos custom-made at the Brush Electric Company. Short then moved to Cleveland to supervise the work and experiment in the company's shops. Brush not only encouraged Short's efforts but helped to finance the resulting Short Electric Railway Company, which operated out of a Brush building. Short sold the company to General Electric in 1892 and then reentered the business almost immediately by joining forces with the Walker Manufacturing Company, a cable and machinery builder, to develop an electric traction system. Short served as vice president of that company until Westinghouse bought control in 1898. That same year, Short left for England to help Dick, Kerr \& Company, Ltd., prepare to manufacture his railway equipment, assuming the position of technical director of the English Electric Manufacturing Company. He died in England in 1902, leaving an estate worth about 2.5 million dollars (Short 1899; Smith 1955; Dictionary of American Biography; Moley 1962, 33-34).

Sperry, Elmer A. 52 patents in sampled years. Assignees at issue: Cleveland Machine Screw Company (2 in 1898 and 4 in 1900); National Battery Company (3 in 1902, 5 in 1903, and 1 in 1905); General Electric (1 in 1903); Safety Car Heating and Lighting Company (1 in 1906); Goodman Manufacturing Company, Chicago (1 in 1907). His patents pertained to motor vehicle storage batteries, gearing, electric railways, preserving perishable goods, a heating apparatus, and refining tin. He maintained his status as an independent inventor, forming only temporary attachments with the firms to which he assigned patents.

1897-8 Cleveland Directory: manager of the Sperry Engineering Co. (motor carriages) 1906-7 Directory: not listed

Sperry was born in 1860 in Cortland, New York. He attended Cortland Normal, finishing in 1880, and also sat in on lectures at Cornell, where he discussed technical problems with Professor William A. Anthony. With backing from Cortland Wagon Co, he developed an arc lighting system and then incorporated the Sperry Electric Light, Motor, and Car Brake Company of Chicago in 1883. The company was not very successful and went through several changes in ownership. From 1888-92, he ran the Elmer A. Sperry Co. of Chicago, a research and development enterprise. Inventions he made during that time led to the formation of the Sperry Electric Mining Machine Company in 1889 and the Sperry Electric Railway Company in 1892. He moved his family to Cleveland in 1893, where he was developing his streetcar inventions with the aid of local financiers. Cleveland backers also financed his work on electric automobiles. In 1898 he convinced 
the Cleveland Machine Screw to tool up to produce his cars in quantity. He assigned his patents on electric vehicles to the company, receiving stock in return and for a time worked as the company's chief electrical engineer. In 1900, the American Bicycle Company took over this business (and Sperry's patents). The same deal led to the formation of the National Battery Company to manufacture a storage battery invented by Sperry. He then got interested in electrochemistry, moving to Brooklyn, New York, in 1905 to work on a detinning process for the American Can Company. He remained in New York for the rest of his life (he died in 1930), turning out inventions ranging from gyro stabilizers and compasses for ships to devices to control and direct machine gun batteries to automatic pilots for aircraft to detectors to spot flaws in railroad tracks. Sperry either assigned the resulting patents to existing companies or helped financiers organize companies (usually bearing his name) to exploit them commercially (Hughes 1971; Hunsaker 1955).

Stearns, Frank B. 1 patent in sampled years, not assigned at issue. Patent was for a gripper for a printing press. Was a principle in a firm that bore his name. Was a "Great Inventor," most of whose patents were outside the sample period.

1897-8 Cleveland Directory: not listed 1906-7 Directory: president of the F. B. Stearns Co.

Stearns was born in 1878 in Berea, Ohio. He graduated from University School in Cleveland in 1894 and then went to the Case School of Applied Science, leaving after one year to pursue his longstanding passion for automobiles. With capital provided initially by his father, who owned a stone quarry and speculated in real estate, he organized the F. B. Stearns Co. in 1898, serving in the office of president. The company's automobiles embodied many of Stearns's inventions. In 1912, however, Stearns recognized the superiority of a new engine design by Charles Y. Knight and joined forces with that inventor to offer the famous Stearns-Knight authomobile. In 1918 a dispute over engineering policies spurred him to retire, but he continued to serve the firm as a consultant. During the 1920s he worked on diesel engines and obtained sixteen patents. He died in 1955 (Dictionary of American Biography; Los Angeles Times, 9 Feb. 1913, p. VII5; Collection Register, Frank B. Stearns Diary, 1915, Ms. 3481, Western Reserve History Society).

Sundt, Oscar. 5 patents in sampled years. Assignee at issue: Garrett-Cromwell Engineering Company (4 patents in 1902). Patents included a rope transmission, charging buggy, and rotary shears. May have been an employee of the firm to which he assigned most of his patents.

1897-8 Cleveland Directory: draftsman 1906-7 Directory: not listed

Tower, Clinton A. 17 patents in sampled years. Assignee at issue: National Malleable Castings Company (all patents except 1 in 1899 and 2 in 1903). Patents were generally for car couplings. Was an employee of the firm to which he assigned most of his inventions. 
1897-8 Cleveland Directory: patternmaker 1906-7 Directory: same

Tower was a foreman of National Malleable's pattern shop when he developed a railroad coupler that could connect and lock automatically but could also be unlocked by a lever on the side of the car. In 1892 he applied for patent on the device, which National Malleable then commercialized (National Malleable and Steel Castings Company 1943, 8 ; Rose 1950, 555).

Van Develde, John. 5 patents in sampled years. Assignee at issue: H. H. Hyman (shares of 2 patents in 1898). Patents included devices for a paper barrel and for barrel making. Cannot determine occupation or relationship with assignee.

1897-8 Cleveland Directory: two listed, one a boltmaker and the other assistant general manager of the Wilson-Clark Co. (oil and water purifiers)

1906-7 Directory: not listed

Wellman, Charles H. 27 patents in sampled years, many joint with Samuel T. Wellman and/or John W. Seaver. Assignees at issue: Wellman-Seaver Engineering Company; Wellman-SeaverMorgan Engineering Co; J. Kennedy, Pittsburg, PA, trustee (assigned all patents except 2 in 1898, 1 in 1900, 5 in 1903, 1 in 1905, 2 in 1906, 2 in 1907). Patents include devices for furnace charging, ingot heating, and the manufacture of basic open hearth steel. Was a principal of the firm to which he assigned most of his patents.

1897-8 Cleveland Directory: engineer of the Wellman-Seaver Engineering Co 1906-7 Directory: deceased

Organized the Wellman-Seaver Engineering Company (later Wellman-Seaver-Morgan) with John W. Seaver (see above) and Samuel T. Wellman (see below).

Wellman, Samuel T. 21 patents in sampled years, many of them joint with Charles H. Wellman and/or John W. Seaver. Assignees at issue: Wellman-Seaver Engineering Company; WellmanSeaver-Morgan Engineering Co; J. Kennedy, Pittsburg, PA, trustee; C. H. Morgan (assigned all patents except 3 in 1898, 1 in 1899, 2 in 1900, 2 in 1905, 1 in 1906, and 2 in 1907). Patents concern railway cars, gas purifiers, methods of treating steel for casting, and themanufacture of basic open hearth steel.

1897-8 Cleveland Directory: president of the Wellman-Seaver Engineering Co. 1906-7 Directory: president of Wellman-Seaver-Morgan and of Electric Controller and Supply Co.

Wellman was born in 1847 in Wareham, Massachusetts. His father was an iron worker who rose to the position of superintendent of the Nashua Iron Company. Wellman attended local public schools and then studied engineering at Norwich University in Vermont until he enlisted in the Union Army in 1863. After the Civil War he worked as a draftsman and engineer at the Nashua works, earning recognition by successfully constructing a Siemens regenerative gas furnace under license from the German firm. 
Wellman was immediately hired by Siemens's U.S. representative, J. T. Potts, to help build furnaces at other works. After he left Siemens's employ, he built an open-hearth furnace (the first commercially successful one in the United States) for the Bay State Iron Company using a plan designed by French engineers. In 1870 he returned to Nashua to take charge of charge of building and running a new steel department. Then in 1873 he moved to Cleveland to do the same for the Otis Iron \& Steel Company. He received an ownership interest and the title of chief engineer and superintendent and stayed with the firm for sixteen years. During this time he obtained a number of patents for inventions that included a hydraulic crane and an open-hearth charging machine. In 1886 Wellman built an experimental furnace at Otis and produced the first basic open-hearth steel in the U.S. Because the process was slower than the more conventional acid process, the firm discontinued the experiment. In 1889, Wellman left the company and worked briefly as a consultant for the Illinois Steel Company. In 1890 he and his half brother, Charles, founded the Wellman Steel Company, which operated a rolling mill in Chester, Pennsylvania, until it failed in 1895. The next year the Wellmans joined forces with John W. Seaver to organize the Wellman-Seaver Engineering Company, a consulting firm that built iron and steel works on contract. Thomas R. Morgan joined the firm in 1901, and it was reorganized in 1903 as the Wellman-Seaver-Morgan Company, an Ohio corporation, in order to acquire the assets of the Webster, Camp \& Lane Company of Akron. Wellman served as president of the American Society of Mechanical Engineers in 190001 and also served at various times as director of East End Bank \& Trust, Dime Savings \& Banking, Cleveland Trust, Iroquois Portland Cement, and Dow Chemical. He died in 1919 (Wellman 1902; Samuel T. Wellman Collection, Kelvin Smith Library, Case Western Reserve University; Sicilia 1989; Dictionary of American Biography; "Dravo Wellman Co.," Encyclopedia of Cleveland History; Wellman Engineering Co. 1956; Rose 1950, 388-89, 429, 488, 568-69, 582).

White, Rollin H. 25 patents in sampled years. Assignees at issue: A.L. Moore Company (1 in 1898); White Sewing Machine Company (1 in 1900, 4 in 1902, 8 in 1903, 3 in 1905, 1 in 1906, and 1 in 1907). Patents include 'steering mechanisms for autos', 'airpumps for autos', 'golfclub', gasoline burner', and 'transmission'. The businesses to which he assigned many of his patents were associated with his family. He later became a principle in firm formed to exploit his inventions.

1897-8 Cleveland Directory: superintendent of A. L. Moore Co. (bicycle material). 1906-7 Directory: superintendent of the automobile department of the White Sewing Machine Co.

White was born in Cleveland in 1872. His father, Thomas H. White, was a founder of the White Sewing Machine Company, the Cleveland Machine Screw Company, and other concerns. Graduating from Cornell in 1894, Rollin went to work at his father's various companies. While he was working at the A. L. Moore Company, which his father had acquired, he and his brother Windsor developed a bicycle which the Sewing Machine Company then manufactured and distributed. In 1899 Rollin invented a flash boiler for steam automobiles and introduced the first White steamer in 1900 (he raced his cars, setting a world record for steam cars in 1901). Rollin's cars (and later trucks) were produced by the White Sewing Machine Company until the family incorporated the 
White Company in 1906. Rollin became its vice president but mainly supervised technological development and production, while two of his brothers took charge of the business aspects of the firm. Rollin always felt underappreciated by his family and left the company in 1914 to pursue inventions in agricultural equipment. He incorporated the Cleveland Motor Plow Company (later Cletrac) in 1916. Maintaining the presidency of Cletrac, he returned in 1923 to automobiles with the incorporation of the Rollin Motors Company. He died in 1962 ("White, Rollin Henry," "White, Thomas H.," "The White Motor Corp.," and "Cletrac, Inc." Encyclopedia of Cleveland History; Hritsko 1988; Wager 1986, 53-68, 186-89; Thomas S. White Family Papers and Rollin H. White and Walter C. White Papers, Western Reserve Historical Society).

von Zweigbergk, Thorsten. 26 patents in sampled years. Assignees at issue: Walker Company (6 in 1898); Westinghouse Electric and Manufacturing Company (1 in 1900). Patents included a controller, magnetic brake, and motor starting device. Was a principal in a firm that bore his name but his status at the time he assigned to Walker and Westinghouse is not known.

1897-8 Cleveland Directory: T.L.A. [??]

1906-7 Directory: president of the Von Zweigbergk Controller Co.

von Zeigbergk was born in Sweden in 1871, entered the United States in 1892, and was naturalized in 1899 (Cayahoga County Genealogy and History n.d.) 
TABLE 1

Manufacturing IN CUyahoga County, Ohio, 1860 -1920

\begin{tabular}{|c|c|c|c|c|}
\hline & $\begin{array}{c}\text { Ranking by } \\
\text { Average Firm } \\
\text { Size out of } \\
\text { Top } 100 \\
\text { Manufacturing } \\
\text { Counties }\end{array}$ & Manufacturing & $\begin{array}{c}\text { Average } \\
\text { Number of } \\
\text { Workers per } \\
\text { Firm }\end{array}$ & $\begin{array}{c}\text { Average } \\
\text { Number of } \\
\text { Workers per } \\
\text { Firm, Top } 100 \\
\text { Manufacturing }\end{array}$ \\
\hline Year & Counties & $\frac{\text { Output }(\$ 000)}{884}$ & & Counties \\
\hline 1850 & NA & 884 & NA & NA \\
\hline 1860 & 59 & 6,973 & 11.5 & 15.76 \\
\hline 1870 & 66 & 27,049 & 8.8 & 13.79 \\
\hline 1880 & 44 & 50,910 & 17.9 & 18.27 \\
\hline 1890 & 35 & 116,466 & 21.5 & 16.43 \\
\hline 1900 & 20 & 156,760 & 23.2 & 17.33 \\
\hline 1910 & NA & NA & NA & NA \\
\hline 1920 & 52 & $1,158,922$ & 53.5 & 47.84 \\
\hline
\end{tabular}

Source: University of Virginia Geospatial and Statistical Data Center. 
TABLE 2

Cleveland's LARGEST INDUSTRIES, 1870-1920

\begin{tabular}{|c|c|c|c|c|c|c|}
\hline $\begin{array}{c}\text { Industry } \\
\text { Rank }\end{array}$ & $1870 *$ & 1880 & 1890 & 1900 & 1910 & 1920 \\
\hline 1 & $\begin{array}{l}\text { Coal, } \\
\text { rectified }\end{array}$ & $\begin{array}{l}\text { Iron and } \\
\text { steel }\end{array}$ & $\begin{array}{c}\text { Iron and } \\
\text { steel }\end{array}$ & $\begin{array}{l}\text { Iron and } \\
\text { steel } \\
\text { Foundry }\end{array}$ & $\begin{array}{c}\text { Iron and } \\
\text { steel, steel } \\
\text { works and } \\
\text { rolling } \\
\text { mills } \\
\text { Foundry }\end{array}$ & $\begin{array}{l}\text { Automo- } \\
\text { biles }\end{array}$ \\
\hline 2 & $\begin{array}{l}\text { Iron, } \\
\text { forged and } \\
\text { rolled }\end{array}$ & $\begin{array}{l}\text { Slaughter- } \\
\text { ing and } \\
\text { meat- } \\
\text { packing }\end{array}$ & $\begin{array}{l}\text { Foundry } \\
\text { and } \\
\text { machine } \\
\text { shops }\end{array}$ & $\begin{array}{l}\text { Foundry } \\
\text { and } \\
\text { machine- } \\
\text { shop } \\
\text { products }\end{array}$ & $\begin{array}{l}\text { Foundry } \\
\text { and } \\
\text { machine- } \\
\text { shop } \\
\text { products }\end{array}$ & $\begin{array}{l}\text { Foundry } \\
\text { and } \\
\text { machine } \\
\text { tool }\end{array}$ \\
\hline 3 & $\begin{array}{l}\text { Flour-mill } \\
\text { products }\end{array}$ & $\begin{array}{l}\text { Foundry } \\
\text { and } \\
\text { machine- } \\
\text { shop } \\
\text { products }\end{array}$ & $\begin{array}{l}\text { Petroleum, } \\
\text { refining } \\
\text { Slaughter- }\end{array}$ & $\begin{array}{l}\text { Slaughter- } \\
\text { ing and } \\
\text { meatpack- } \\
\text { ing, } \\
\text { wholesale }\end{array}$ & $\begin{array}{l}\text { Automo- } \\
\text { biles }\end{array}$ & $\begin{array}{l}\text { Iron and } \\
\text { steel }\end{array}$ \\
\hline 4 & $\begin{array}{c}\text { Meat, } \\
\text { packed } \\
\text { pork } \\
\text { Iron, } \\
\text { castings }\end{array}$ & $\begin{array}{l}\text { Clothing, } \\
\text { men's }\end{array}$ & $\begin{array}{l}\text { ing and } \\
\text { meatpack- } \\
\text { ing, } \\
\text { wholesale }\end{array}$ & $\begin{array}{l}\text { Clothing, } \\
\text { women's } \\
\text { factory } \\
\text { product }\end{array}$ & $\begin{array}{l}\text { Slaughter- } \\
\text { ing and } \\
\text { meatpack- } \\
\text { ing }\end{array}$ & $\begin{array}{l}\text { Electrical } \\
\text { machinery }\end{array}$ \\
\hline 5 & $\begin{array}{c}\text { (not } \\
\text { specified) }\end{array}$ & $\begin{array}{c}\text { Liquors, } \\
\text { malt }\end{array}$ & $\begin{array}{c}\text { Carpenter- } \\
\text { ing }\end{array}$ & $\begin{array}{c}\text { Liquors, } \\
\text { malt }\end{array}$ & $\begin{array}{l}\text { Clothing, } \\
\text { women's }\end{array}$ & $\begin{array}{l}\text { Clothing, } \\
\text { women's }\end{array}$ \\
\hline
\end{tabular}

*1870 data are for Cuyahoga County. All other years are for the city of Cleveland.

Sources: U.S. Census, 1870-1920. 
TABLE 3

Distribution of Patents by Assignee Type, Patentee Cohort, AND NUMBER OF CAREER PATENTS

\begin{tabular}{|c|c|c|c|c|}
\hline \multirow[b]{2}{*}{$\begin{array}{l}\text { Type of Assignee, } \\
\text { if Any }\end{array}$} & \multicolumn{4}{|c|}{ Categories of Patentees by Career Patents } \\
\hline & $\begin{array}{l}\text { 1-2 Patents } \\
\text { (Col. \%) }\end{array}$ & $\begin{array}{l}\text { 3-5 Patents } \\
\text { (Col. \%) }\end{array}$ & $\begin{array}{l}\text { 6-9 Patents } \\
\text { (Col. \%) }\end{array}$ & $\begin{array}{l}\text { 10+ Patents } \\
\text { (Col. \%) }\end{array}$ \\
\hline \multicolumn{5}{|l|}{ Not Assigned } \\
\hline 1870-71 Cohort & 82.4 & 88.6 & 87.7 & 75.3 \\
\hline 1890-91 Cohort & 72.9 & 70.5 & 60.6 & 45.6 \\
\hline 1910-11 Cohort & 85.0 & 78.1 & 57.5 & 37.6 \\
\hline \multicolumn{5}{|c|}{$\begin{array}{l}\text { Assigned Share to Indi- } \\
\text { vidual }\end{array}$} \\
\hline 1870-71 Cohort & 10.3 & 3.6 & 4.1 & 5.5 \\
\hline 1890-91 Cohort & 10.0 & 11.6 & 12.8 & 3.9 \\
\hline 1910-11 Cohort & 7.5 & 6.5 & 5.8 & 2.6 \\
\hline \multicolumn{5}{|c|}{$\begin{array}{l}\text { Assigned in Full to Indi- } \\
\text { vidual }\end{array}$} \\
\hline 1870-71 Cohort & 2.9 & 5.0 & 2.5 & 8.8 \\
\hline 1890-91 Cohort & 2.9 & 8.5 & 6.4 & 9.6 \\
\hline 1910-11 Cohort & 1.5 & 3.2 & 1.7 & 3.0 \\
\hline \multicolumn{5}{|l|}{$\begin{array}{l}\text { Assigned to Company } \\
\text { with Same Name }\end{array}$} \\
\hline 1870-71 Cohort & 0.0 & 0.0 & 0.0 & 1.7 \\
\hline 1890-91 Cohort & 0.0 & 1.6 & 3.7 & 6.1 \\
\hline 1910-11 Cohort & 0.0 & 0.0 & 5.8 & 23.5 \\
\hline \multicolumn{5}{|c|}{$\begin{array}{l}\text { Assigned to Large Inte- } \\
\text { grated Company }\end{array}$} \\
\hline 1870-71 Cohort & 0.0 & 0.0 & 0.8 & 1.2 \\
\hline 1890-91 Cohort & 1.4 & 0.0 & 0.5 & 9.9 \\
\hline 1910-11 Cohort & 0.0 & 1.9 & 0.0 & 14.1 \\
\hline \multicolumn{5}{|c|}{ Assigned to Other Local } \\
\hline \multicolumn{5}{|l|}{ Company } \\
\hline 1870-71 Cohort & 1.5 & 0.7 & 2.5 & 4.5 \\
\hline 1890-91 Cohort & 10.0 & 3.9 & 5.3 & 15.9 \\
\hline 1910-11 Cohort & 1.5 & 3.9 & 15.8 & 8.0 \\
\hline \multicolumn{5}{|c|}{$\begin{array}{l}\text { Assigned to Other Com- } \\
\text { pany }\end{array}$} \\
\hline 1870-71 Cohort & 2.9 & 2.1 & 2.5 & 2.9 \\
\hline 1890-91 Cohort & 4.3 & 3.9 & 10.6 & 9.0 \\
\hline 1910-11 Cohort & 3.9 & 6.5 & 13.3 & 6.7 \\
\hline \multicolumn{5}{|l|}{ Number of Patents } \\
\hline 1870-71 Cohort & 68 & 140 & 122 & 749 \\
\hline 1890-91 Cohort & 80 & 129 & 188 & 2060 \\
\hline 1910-11 Cohort & 133 & 155 & 120 & 1860 \\
\hline
\end{tabular}


Notes and Sources: The table is based on a longitudinal data set constructed by selecting all of the inventors whose family names began with the letter "B" from three random cross-sectional samples drawn from the Annual Reports of the Commissioner of Patents for the years 1870-71, 1890-91, and 1910-11. We then collected from the Annual Reports all of the patents received by these inventors during the twenty-five years before and after they appeared in the samples, including information on whether and to whom the patents were assigned. Companies to whom the patentees assigned their inventions were classified as follows: We first checked to see whether the assignee was a company with the same name as the patentee. If not, we classified as "large integrated companies" all assignees for which financial information was reported in the Commercial and Financial Chronicle or in Poor's or Moody's Manual of Industrial Securities (indicating that the company was important enough to tap the national capital markets) or, alternatively, that were listed in an early-1920s National Research Council directory of companies with research laboratories. The remaining companies were divided into two groups: "other local companies," if the assignee was located in the same city as the patentee; and "other companies" for all the rest. 
TABLE 4

Distribution of PATENTS By Assignee TyPe, COHORT, AND REgiON

\begin{tabular}{|c|c|c|c|}
\hline \multirow[b]{2}{*}{ Type of Assignee, if Any } & \multicolumn{3}{|c|}{ Region } \\
\hline & $\begin{array}{c}\text { New } \\
\text { England } \\
(\text { Col. \%) }\end{array}$ & $\begin{array}{l}\text { Middle } \\
\text { Atlantic } \\
(\text { Col. \%) }\end{array}$ & $\begin{array}{c}\text { East North } \\
\text { Central } \\
(\text { Col. \%) }\end{array}$ \\
\hline \multicolumn{4}{|l|}{ Not Assigned } \\
\hline 1870-71 Cohort & 76.1 & 75.6 & 83.0 \\
\hline 1890-91 Cohort & 24.7 & 58.1 & 51.3 \\
\hline 1910-11 Cohort & 35.0 & 38.1 & 44.6 \\
\hline \multicolumn{4}{|c|}{ Assigned Share to Individual } \\
\hline 1870-71 Cohort & 3.7 & 5.5 & 8.3 \\
\hline 1890-91 Cohort & 3.8 & 5.3 & 4.8 \\
\hline 1910-11 Cohort & 3.7 & 2.0 & 3.1 \\
\hline \multicolumn{4}{|c|}{ Assigned in Full to Individual } \\
\hline 1870-71 Cohort & 10.6 & 8.3 & 2.3 \\
\hline 1890-91 Cohort & 7.8 & 4.5 & 18.3 \\
\hline 1910-11 Cohort & 5.2 & 3.2 & 2.1 \\
\hline \multicolumn{4}{|c|}{ Assigned to Company with Same Name } \\
\hline 1870-71 Cohort & 0.6 & 2.3 & 0.5 \\
\hline 1890-91 Cohort & 3.4 & 5.0 & 6.8 \\
\hline 1910-11 Cohort & 23.0 & 2.7 & 31.4 \\
\hline \multicolumn{4}{|c|}{ Assigned to Large Integrated Company } \\
\hline 1870-71 Cohort & 0.0 & 0.0 & 0.0 \\
\hline 1890-91 Cohort & 15.5 & 9.4 & 3.8 \\
\hline 1910-11 Cohort & 23.0 & 22.1 & 4.1 \\
\hline \multicolumn{4}{|c|}{ Assigned to Other Local Company } \\
\hline 1870-71 Cohort & 7.5 & 3.9 & 1.0 \\
\hline 1890-91 Cohort & 30.8 & 9.5 & 10.6 \\
\hline 1910-11 Cohort & 3.7 & 8.2 & 8.4 \\
\hline \multicolumn{4}{|l|}{ Assigned to Other Company } \\
\hline 1870-71 Cohort & 1.6 & 4.4 & 0.0 \\
\hline 1890-91 Cohort & 14.1 & 8.2 & 4.4 \\
\hline 1910-11 Cohort & 6.5 & 23.8 & 6.4 \\
\hline \multicolumn{4}{|l|}{ Number of Patents } \\
\hline 1870-71 Cohort & 322 & 434 & 218 \\
\hline 1890-91 Cohort & 555 & 947 & 707 \\
\hline 1910-11 Cohort & 383 & 601 & 1050 \\
\hline
\end{tabular}

Notes and Sources: See Table 1. 
TABLE 5

Changes Over Cohorts in Patentees’ Contractual Mobility, By Region

\begin{tabular}{|c|c|c|c|c|c|}
\hline \multirow[b]{2}{*}{ Number of Assignees } & \multicolumn{4}{|c|}{ Region of Patentee } & \multirow[b]{2}{*}{$\mathrm{n}$} \\
\hline & $\begin{array}{c}\text { New } \\
\text { England } \\
(\text { Col. \%) }\end{array}$ & $\begin{array}{l}\text { Middle } \\
\text { Atlantic } \\
(\text { Col. \%) }\end{array}$ & $\begin{array}{c}\text { East North } \\
\text { Central } \\
(\text { Col. \%) }\end{array}$ & $\begin{array}{c}\text { Other U.S } \\
\text { (Col. \%) }\end{array}$ & \\
\hline \multicolumn{6}{|l|}{ No Assignees } \\
\hline 1870-71 Cohort & 51.2 & 64.8 & 60.5 & 57.1 & 87 \\
\hline 1890-91 Cohort & 25.7 & 42.4 & 36.7 & 41.7 & 69 \\
\hline 1910-11 Cohort & 34.8 & 48.4 & 55.0 & 60.4 & 111 \\
\hline \multicolumn{6}{|l|}{1 Assignee } \\
\hline 1870-71 Cohort & 39.0 & 18.5 & 26.3 & 14.3 & 38 \\
\hline 1890-91 Cohort & 28.6 & 12.1 & 38.3 & 33.3 & 49 \\
\hline 1910-11 Cohort & 17.4 & 29.0 & 13.8 & 27.1 & 46 \\
\hline \multicolumn{6}{|l|}{ 2-3 Different Assignees } \\
\hline 1870-71 Cohort & 2.4 & 9.3 & 5.3 & 21.4 & 11 \\
\hline 1890-91 Cohort & 25.7 & 25.8 & 16.7 & 12.5 & 39 \\
\hline 1910-11 Cohort & 34.8 & 12.9 & 18.8 & 10.4 & 36 \\
\hline \multicolumn{6}{|l|}{ 4+ Different Assignees } \\
\hline 1870-71 Cohort & 7.3 & 7.4 & 7.9 & 7.1 & 11 \\
\hline 1890-91 Cohort & 20.0 & 19.7 & 8.3 & 12.5 & 28 \\
\hline 1910-11 Cohort & 13.0 & 9.7 & 12.5 & 2.1 & 20 \\
\hline \multicolumn{6}{|l|}{ 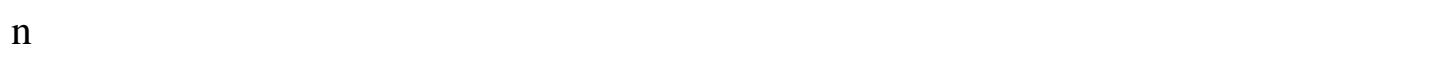 } \\
\hline 1870-71 Cohort & 41 & 54 & 38 & 14 & 147 \\
\hline 1890-91 Cohort & 35 & 66 & 60 & 24 & 185 \\
\hline 1910-11 Cohort & 23 & 62 & 80 & 48 & 213 \\
\hline
\end{tabular}

Notes and Sources: See Table 1. Each patentee is represented in the table by one patent that was randomly selected from his list of career patents. 
TABLE 6

Distribution of PATENTS By Assignee TyPe AND Stage of CAREER

\begin{tabular}{|c|c|c|c|}
\hline \multirow[b]{2}{*}{ Type of Assignee, if Any } & \multicolumn{3}{|c|}{ Stage of Career } \\
\hline & $\begin{array}{c}\leq 5 \text { Years } \\
\text { Since First } \\
\text { Patent } \\
(\text { Col. } \%)\end{array}$ & $\begin{array}{c}>5 \text { Years } \\
\text { and } \leq 15 \\
\text { Years Since } \\
\text { First Patent } \\
(\text { Col. } \%)\end{array}$ & $\begin{array}{c}>15 \text { Years } \\
\text { Since First } \\
\text { Patent } \\
(\text { Col. } \%)\end{array}$ \\
\hline \multicolumn{4}{|l|}{ Not Assigned } \\
\hline 1870-71 Cohort & 81.9 & 75.3 & 68.9 \\
\hline 1890-91 Cohort & 62.0 & 52.7 & 36.6 \\
\hline 1910-11 Cohort & 45.6 & 50.3 & 29.7 \\
\hline \multicolumn{4}{|c|}{ Assigned Share to Individual } \\
\hline 1870-71 Cohort & 6.2 & 6.7 & 3.6 \\
\hline 1890-91 Cohort & 4.0 & 5.4 & 3.0 \\
\hline 1910-11 Cohort & 6.9 & 4.0 & 0.8 \\
\hline \multicolumn{4}{|c|}{ Assigned in Full to Individual } \\
\hline 1870-71 Cohort & 4.1 & 11.4 & 10.8 \\
\hline 1890-91 Cohort & 12.1 & 11.1 & 8.0 \\
\hline 1910-11 Cohort & 7.2 & 3.1 & 1.8 \\
\hline \multicolumn{4}{|c|}{ Assigned to Company with Same Name } \\
\hline 1870-71 Cohort & 0.4 & 0.0 & 4.8 \\
\hline 1890-91 Cohort & 2.2 & 4.2 & 8.4 \\
\hline 1910-11 Cohort & 1.3 & 17.1 & 32.6 \\
\hline \multicolumn{4}{|c|}{ Assigned to Large Integrated Company } \\
\hline 1870-71 Cohort & 0.0 & 0.0 & 0.0 \\
\hline 1890-91 Cohort & 7.1 & 6.3 & 12.9 \\
\hline 1910-11 Cohort & 12.1 & 7.3 & 17.8 \\
\hline \multicolumn{4}{|c|}{ Assigned to Other Local Company } \\
\hline 1870-71 Cohort & 6.6 & 3.1 & 7.6 \\
\hline 1890-91 Cohort & 8.4 & 15.1 & 18.6 \\
\hline 1910-11 Cohort & 17.1 & 11.7 & 3.8 \\
\hline \multicolumn{4}{|c|}{ Assigned to Other Company } \\
\hline 1870-71 Cohort & 0.8 & 3.5 & 4.4 \\
\hline 1890-91 Cohort & 4.3 & 5.4 & 12.6 \\
\hline 1910-11 Cohort & 9.8 & 6.5 & 5.9 \\
\hline \multicolumn{4}{|l|}{ Number of Patents } \\
\hline 1870-71 Cohort & 243 & 255 & 251 \\
\hline 1890-91 Cohort & 323 & 651 & 1086 \\
\hline 1910-11 Cohort & 305 & 479 & 1076 \\
\hline
\end{tabular}

Notes and Sources: See Table 1. Only patents awarded to patentees with ten or more career patents are included in this table. 
TABLE 7

Distribution of Cleveland PATENTS By AssigneE TyPe

\begin{tabular}{lcc}
\hline \hline & $1898-1902$ & $1910-1912$ \\
Type of Assignee, if Any & Sample & Sample \\
\hline $\begin{array}{c}\text { Not Assigned } \\
\text { number }\end{array}$ & 395 & 271 \\
percent & $(47.1)$ & $(44.8)$ \\
Assigned to Individual & & \\
number & 30 & 27.5 \\
percent & $(3.6)$ & $(4.5)$ \\
Assigned to Company where & & \\
$\quad \begin{array}{l}\text { Patentee is Principal } \\
\text { number } \\
\text { percent }\end{array}$ & 148 & 118.5 \\
Assigned to National Company & $(17.6)$ & $(19.6)$ \\
$\quad$ number & & \\
percent & 95 & 121 \\
Assigned to Local Company & $(11.3)$ & $(20.0)$ \\
$\quad$ number & & \\
percent & 77 & 58 \\
Assigned to Other Company & $(9.2)$ & $(9.6)$ \\
number & & \\
percent & 90 & 10 \\
Total Number of Patents & $(10.7)$ & $(1.7)$ \\
\hline
\end{tabular}

Notes and Sources: The 1898-1902 sample (36 patentees) consisted of inventors who were Cleveland residents, obtained a patent in 1900, and had a total of at least three patents in 1898, 1900, 1902, as well as several inventors resident in Cleveland who were prominent enough to be profiled in the Dictionary of American Biography. The patent record for this sample consists of all patents they were awarded in 1892 through 1912, except for the years 1895, 1901, and 1904. The 1910-1912 sample (107 patentees) consists of inventors resident in Cleveland who received a patent in 1912 and at least three patents during 1910, 1911, and 1912. The patent record for this sample consists of their total patents for these three years. 
TABLE 8

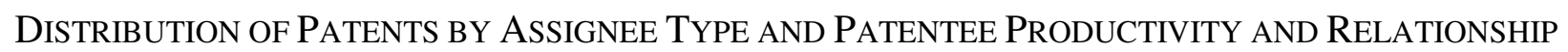
TO AssigneE

\begin{tabular}{|c|c|c|c|c|c|}
\hline \multirow[b]{2}{*}{$\begin{array}{l}\text { Type of Assignee, } \\
\text { if Any }\end{array}$} & \multicolumn{5}{|c|}{ Category of Patentee } \\
\hline & $\begin{array}{c}1-5 \text { Patents } \\
\text { (6 inventors, } \\
1 \text { principal) }\end{array}$ & $\begin{array}{l}6-15 \text { Patents } \\
\text { (9 inventors, } \\
5 \text { principals) }\end{array}$ & $\begin{array}{c}>15 \text { Patents } \\
\text { and } \\
\text { Principal } \\
\\
(n=13) \\
\end{array}$ & $\begin{array}{l}\quad>15 \\
\text { Patents } \\
\text { and Not a } \\
\text { Principal } \\
\qquad(\mathrm{n}=7)\end{array}$ & Total \\
\hline $\begin{array}{c}\text { Not Assigned } \\
\text { number } \\
\text { percent }\end{array}$ & $\begin{array}{c}9 \\
(60.0)\end{array}$ & $\begin{array}{c}41 \\
(49.4)\end{array}$ & $\begin{array}{l}269 \\
(61.0)\end{array}$ & $\begin{array}{c}76 \\
(25.3)\end{array}$ & $\begin{array}{l}395 \\
(47.1)\end{array}$ \\
\hline $\begin{array}{l}\text { Assigned to } \\
\text { Individual } \\
\text { number } \\
\text { percent }\end{array}$ & $\begin{array}{c}2 \\
(13.3)\end{array}$ & $\begin{array}{c}6 \\
(7.2)\end{array}$ & $\begin{array}{l}14 \\
(3.2)\end{array}$ & $\begin{array}{c}8 \\
(2.7)\end{array}$ & $\begin{array}{c}30 \\
(3.6)\end{array}$ \\
\hline $\begin{array}{l}\text { Assigned to } \\
\text { Company } \\
\text { where Patentee } \\
\text { is Principal } \\
\text { number } \\
\text { percent }\end{array}$ & $\begin{array}{c}0 \\
(0.0)\end{array}$ & $\begin{array}{c}21 \\
(25.3)\end{array}$ & $\begin{array}{l}116 \\
(26.3)\end{array}$ & $\begin{array}{c}11 \\
(3.7)\end{array}$ & $\begin{array}{c}148 \\
(17.6)\end{array}$ \\
\hline $\begin{array}{l}\text { Assigned to } \\
\text { National } \\
\text { Company } \\
\text { number } \\
\text { percent }\end{array}$ & $\begin{array}{c}0 \\
(0.0)\end{array}$ & $\begin{array}{c}0 \\
(0.0)\end{array}$ & $\begin{array}{c}9 \\
(2.0)\end{array}$ & $\begin{array}{c}86 \\
(28.7)\end{array}$ & $\begin{array}{c}95 \\
(11.3)\end{array}$ \\
\hline $\begin{array}{l}\text { Assigned to Local } \\
\text { Company } \\
\text { number } \\
\text { percent }\end{array}$ & $\begin{array}{c}4 \\
(26.7)\end{array}$ & $\begin{array}{c}14 \\
(16.9)\end{array}$ & $\begin{array}{l}25 \\
(5.7)\end{array}$ & $\begin{array}{c}34 \\
(11.3)\end{array}$ & $\begin{array}{c}77 \\
(9.2)\end{array}$ \\
\hline $\begin{array}{l}\text { Assigned to Other } \\
\text { Company } \\
\text { number } \\
\text { percent }\end{array}$ & $\begin{array}{c}0 \\
(0.0)\end{array}$ & $\begin{array}{c}1 \\
(1.2)\end{array}$ & $\begin{array}{c}4 \\
(0.9)\end{array}$ & $\begin{array}{c}85 \\
(28.3)\end{array}$ & $\begin{array}{c}90 \\
(10.7)\end{array}$ \\
\hline $\begin{array}{l}\text { Total Number of } \\
\text { Patents } \\
\text { Row Percent }\end{array}$ & $\begin{array}{l}15 \\
(1.8)\end{array}$ & $\begin{array}{l}83 \\
(9.9)\end{array}$ & $\begin{array}{l}441 \\
(52.6)\end{array}$ & $\begin{array}{l}300 \\
(35.8)\end{array}$ & $\begin{array}{c}839 \\
(100.0)\end{array}$ \\
\hline
\end{tabular}

Notes and Sources: See Table 5. The small number of assignments made by patentees classified as non-principals to firms in which the patentee was a principal involve cases where the patentee's status as principal was brief. 